\title{
Foreigners vs. Natives: Bank Lending Technologies and Loan Pricing
}

\author{
Thorsten Beck* \\ Cass Business School, City University London and CEPR \\ Vasso Ioannidou \\ Lancaster University and CEPR \\ Larissa Schäfer \\ Frankfurt School of Finance \& Management
}

September 2016

\begin{abstract}
Can distance-related information asymmetries in credit markets be overcome with contract design and credit scoring models? To answer this question, we explore differences in foreign and domestic banks' credit contract terms and pricing models. Using a sample of firms that borrow from both domestic and foreign banks in the same month, we show that foreign banks are more likely to demand collateral and grant shorter maturity loans than domestic banks. Foreign banks also base their pricing on internal credit ratings and collateral pledges, while domestic banks price according to the length, depth and breadth of their relationship with a firm. These findings confirm that foreign banks can overcome informational disadvantages using contract design and credit scoring models. However, we also show that there are limitations, with foreign banks facing higher default rates and lower returns on lending if not using collateral and short maturity as disciplining tools.
\end{abstract}

JEL Classification: G21, G30

Keywords: Bank Financing, Foreign Ownership, Lending Technologies, Loan Pricing

\footnotetext{
• Cass Business School, City University London, and CEPR, Email: TBeck@city.ac.uk. We gratefully acknowledge comments by two anonymous referees, Allen Berger, Ricardo Correa, Hans Degryse, Manthos Delis, Mariassunta Giannetti, Michael Kötter, Lars Norden, Daniel Paravisini, Jose-Luis Peydro, Steven Ongena, Greg Udell, Sascha Steffen and seminar participants at Cass Business School, Chinese University of Hong Kong, European Investment Bank, Peking University, Tilburg University and Universidad Carlos III de Madrid and conference participants at the CEPR-ECB-IU-RoF Conference 2012 in Frankfurt, the Emerging Scholars Conference 2012 in London, MoFiR Workshop on Banking 2013 in Ancona and the FIRS 2013 in Dubrovnik. A special thanks goes to Tobias Berg, Sascha Steffen and Anthony Saunders for their help with the Dealscan analysis and Bernardus van Doornik for the analysis using Brazilian credit registry data.
} 


\section{Introduction}

A burgeoning literature on financial intermediation studies the impact of distance-related information frictions between borrowers and lenders in credit markets. Distance-be it geographical, cultural, institutional, or organizational - can aggravate information asymmetries and change incentives in ways that may lead to worse credit outcomes. The large increase in foreign bank entry across the globe and especially in emerging markets is one such example. A view espoused by many scholars is that distancerelated information constraints prevent foreign banks from effectively penetrating less developed markets by influencing who they can lend to and how. This paper studies how foreign banks may be able to overcome distance constraints by comparing the lending practices $^{1}$ and outcomes of domestic and foreign banks. It is novel as it focuses on a group of firms that borrow simultaneously from both domestic and foreign banks, which allows holding constant differences in their clienteles. Understanding whether and how foreign banks may be able to overcome distance constraints and penetrate new and less developed markets is key for understanding the role they can play in such markets and designing supportive policies.

Distance-related information constraints can put foreign banks at an informational disadvantage visà-vis their domestic competitors, particularly when lending to smaller, more opaque firms. Such constraints can arise because of (i) the greater geographical distance between the bank's headquarters (principal) and the local branches (agent), (ii) differences in corporate culture, legal environment, and institutional framework between the home and the host country, and (iii) steeper organizational structures. Due to their typically larger size and legal structure (i.e., a parent abroad), foreign banks have more hierarchical organizational structures (i.e., more layers in the decision making) that create diseconomies in lending to smaller, more opaque firms. The maintained assumption is that lending to such firms relies heavily on "soft" information that is difficult to quantify and transmit to the higher levels of the

\footnotetext{
${ }^{1}$ In the following, we use the terms "lending practices" and "lending technologies" interchangeably. We follow the definition in Berger and Udell (2006) by defining "a lending technology as a unique combination of primary information source, screening and underwriting policies/procedures, loan contract structure, and monitoring strategies and mechanisms." While Degryse, Laeven and Ongena (2009) use the same term, other authors use alternative terms such as lending behavior, bank lending decisions, lending patterns and credit assessment processes (see, among others, Agarwal and Hauswald (2010) and Liberti, Seru and Vig (2016)).
} 
organization, where the credit allocation decision lies. ${ }^{2}$ As a result, foreign banks are often argued to shy away from smaller, more opaque firms and focus primarily on larger, more transparent firms, i.e., focus on the segments of the market where their informational disadvantage vis-à-vis their local competitors is less pronounced as predicted in Dell'Ariccia and Marquez (2004). ${ }^{3}$ Although the evidence is far from conclusive, several studies find indeed that foreign banks tend shy away from smaller firms. ${ }^{4}$

Contract design and credit scoring models, however, can help foreign banks to mitigate their informational disadvantage vis-à-vis their local competitors (see, among others, Berger and Udell (2006) and Sengupta (2007)). Contractual features such as collateral and maturity can be used to mitigate asymmetric information problems in credit markets. An extensive theoretical literature motivates collateral as a way to mitigate ex ante and ex post asymmetric informational frictions in credit markets. ${ }^{5}$ In the absence of reliable and audited financial statements, where lenders cannot rely on debt covenants to ensure entrepreneurial commitment, shorter loan maturities can also serve as an alternative disciplining tool (e.g., Berlin and Mester (1992); Myers (1977)). Lending at shorter maturities can help banks to screen and monitor their clients by forcing more frequent information disclosure and renegotiation of contract terms (e.g., Barnea, Haugen and Senbet (1980); Diamond (1991); Flannery (1986); Hart and Moore

\footnotetext{
2 Theory suggests that private non-verifiable information, often referred to as "soft" information, is difficult to transmit across organizational layers. Reasons vary from reduced incentives to produce such information ex ante in anticipation that it will be ignored at the higher levels of the organization (Aghion and Tirole (1997); Stein (2002)), to incentives to strategically manipulate such information when incentives across the various layers of the organization do not perfectly align (Crawford (1982)), and to the high costs to ex post communicate such information across organizational layers (Bolton and Dewatripont (1994); Radner (1993); Sah and Stiglitz (1986)).

${ }^{3}$ See also Detragiache, Gupta and Tressel (2008), Gormley (2014), and Sengupta (2007).

${ }^{4}$ Using a variety of techniques and samples, several studies document that foreign banks tend to shy away from smaller, more opaque borrowers (see, among others, Beck and Martínez Pería (2010); Berger, Klapper, Martínez Pería and Zaidi (2008); Berger, Klapper and Udell (2001); Clarke, Cull, Martínez Pería and Sanchez (2005); De Haas, Ferreira and Taci (2010); Detragiache, et al. (2008); Gormley (2010); Mian (2006)). Others find that foreign banks are at least as likely to lend to small firms as domestic banks (see, among others, Berger, Rosen and Udell (2007); Clarke, et al. (2005); Giannetti and Ongena (2009); Giannetti and Ongena (2012)) using transaction-based lending, consistent with survey evidence in De la Torre, Martínez Pería and Schmukler (2010) and Beck, DemirgüçKunt and Martínez Pería (2011).

${ }^{5}$ A set of theoretical models focuses on ex ante private information and shows that collateral can be used to sort observationally equivalent borrowers through signaling (e.g., Besanko and Thakor (1987); Bester (1985); Bester (1987); Boot, Thakor and Udell (1991)). A second set of theories focuses on ex post frictions and shows that collateral can mitigate moral hazard and bank losses in the event of borrower default (e.g., Aghion and Bolton (1997); Boot, et al. (1991); Boot and Thakor (1994); Hart and Moore (1994); Holmstrom and Tirole (1997)).
} 
(1994); Rajan (1992)). Credit scoring models can also allow banks to "harden" soft information and transmit it to the higher levels of the organization enabling its use in the credit allocation process. Credit scoring allows banks to compile both hard and soft information into credit scores (e.g., Agarwal and Hauswald (2010); Liberti and Mian (2009); Petersen (2004)) and reduce the adverse impact of distance between banks and their borrowers on loan defaults (DeYoung, Glennon and Nigro (2008)).

Controlling for possible differences in their clienteles, we examine whether foreign banks use contract design and credit scoring models to overcome their informational disadvantage vis-à-vis their local competitors and whether such mechanisms are effective. Informed and motivated by the extant literature, we bring the following predictions to the data. First, if foreign banks use such mechanisms to overcome distance-related information frictions as we argue, we should observe that foreign banks are more likely to require collateral and lend at shorter maturities, even when lending to the same customers in the same month as the domestic banks. Second, foreign banks should be more likely to price their loans using internal credit scores and rely on the provision of collateral, thus using hard(ened) information and hard assets, while domestic banks should rely less on such hard(ened) information and more on soft information acquired through relationships with clients. Third, the tendency to rely on such mechanisms should be larger when information asymmetries are more severe. We should also observe that the use of such mechanisms reduces over time as information asymmetries decrease. Fourth, if such screening and monitoring mechanisms are effective, we should not observe any systematic differences in the ex post performance of domestic and foreign loans, when holding differences in their clienteles constant.

We bring these four predictions to the data. We begin by comparing the contract terms and loan pricing models of domestic and foreign banks within a country, holding constant differences in their clienteles. We eliminate the compositional bias and compare the contract terms and loan pricing models of domestic and foreign banks when lending to exactly the same firm in the same month using both regression and matching analyses. ${ }^{6}$ Exploring within-firm and month variation allows us to control for unobserved firm characteristics. We are thus able to separate the two different effects of foreign bank

\footnotetext{
${ }^{6}$ We additionally control for the firm's length, strength, and breath of its lending relationship with each bank.
} 
entry - the focus on different clienteles and the use of different lending technologies and loan pricing models — by focusing completely on the latter. To examine whether unobserved heterogeneity in the purpose of the loan drives our results, we exploit exogenous (to the firm) variation in bank ownership. Using the takeover of a domestic bank by a foreign bank, we study whether loan contract terms to the same firm change after the takeover using a difference-in-difference analysis. ${ }^{7}$ To examine whether distance-related information constraints are driving the observed differences, we exploit variation in the form of foreign bank entry (branches vs. subsidiaries), time since entry or since becoming foreign owned, and geographical distance between loan origination and the bank's headquarters. In the final part of the analysis, we study the ex post performance of domestic and foreign bank loans by looking at both the incidence of repayment problems as well as the banks' returns on loans.

The analysis uses loan-level data from the public credit registry of Bolivia for the period between March 1999 and December 2003. The data include detailed loan information such as date of loan origination, maturity date, contract terms, loan amount, collateral, maturity, interest rates, the geographical location (region) in which the loan was originated, and ex post repayment information as well as data on firm characteristics such as legal structure, industry, banking relationships, and repayment behavior. ${ }^{8}$ The Bolivian credit market provides a good setting for several reasons. During the sample period, Bolivia's banking sector was fully private, eliminating distortions from government-owned banks. Foreign and domestic banks are subject to the same regulations such that there is no differential regulatory treatment, which could influence our results. Both the number and market shares of domestic and foreign banks are relatively balanced and stable during the sample period, enabling meaningful comparisons (Claessens and van Horen (2014)). Like many other developing countries that recently opened their doors to foreign banks, Bolivia's credit markets are opaque and underdeveloped. Many firms do not have audited financial statements, and if they do, the quality of such statements is often poor (Sirtaine, Skamnelos and Frank

\footnotetext{
${ }^{7}$ To control for changes in the macroeconomic and banking conditions over the comparison period, we use loans to the same firms by their other (non-taken-over) banks both before and after the acquisition as a control group.

${ }^{8}$ While the use of credit registries has become more prominent in recent years, the Bolivian credit registry offers unique advantages. Contrary to many other credit registries, the Bolivian credit registry does not have a reporting threshold (i.e., all loans originated by any formal financial institution are included) and includes detailed and reliable loan-level information on contract terms, including interest rates and collateral, often not available in other registries.
} 
(2004)). Bolivia thus provides a setting with high information asymmetries affecting screening and monitoring of borrowers and a balanced set of both domestic and foreign banks. It is thus interesting to understand how in such an opaque setting foreign banks may be able to overcome their distance-related information constraints and meet firms' financing needs, thus facilitating investment and growth. Bolivia shares with many other developing economies the characteristic of having a small and relatively concentrated banking market, which again makes it a good case to study.

We find that foreign banks are more likely to require collateral and lend at shorter maturities. In particular, when comparing the terms of loans originated by domestic and foreign banks to the same firm in the same month, we find that foreign bank loans are, on average, 28 percentage points more likely to have collateral and have maturities that are about $27 \%$ shorter than domestic bank loans. We also find that foreign banks charge loan interest rates that are, on average, between 89 to 107 basis points lower than the interest rates of domestic banks - a 9\% discount relative to the interest rate of domestic bank loans in the sample. We obtain similar results when we examine how the terms of loans to the same firms change when their (domestic) bank is taken over by a foreign bank. We find an increase in the incidence of collateral by 28 percentage points and a decrease in loan maturity by $48 \%$. Drops in loan interest rates are not found to be statistically significant or as economically important in this exercise. Overall, these results suggest that unobserved heterogeneity in the purpose of the loan is unlikely to be driving the documented differences with respect to collateral and maturity. In additional robustness tests, we confirm these results are not driven by biases arising from the joint determination of contract terms and sample selection.

Distinguishing between foreign banks into branches and subsidiaries reveals that at the point of entry or becoming foreign owned, differences in collateral and maturity (vis-à-vis domestic banks) are more pronounced for branches than subsidiaries. This is not surprising as subsidiaries enjoy greater organizational autonomy from their parent companies. Information asymmetries with respect to the local economy, its culture and institutions are also more pronounced for branches than subsidiaries that are former domestic banks. However, as time since entry increases or becoming foreign owned increases, branches become more like domestic banks, while subsidiaries begin to behave more like foreign banks, in 
line with the expectation that information asymmetries for new entrants decrease, while subsidiaries begin adopting their lending policies to their steeper organizational structure. ${ }^{9}$

When studying how domestic and foreign banks price their loans, we find that domestic banks base their pricing on the length of their relationship with the firm, especially in the case of smaller, more opaque firms. Foreign banks instead have a more transaction-based pricing approach, relying on credit scores and collateral, especially for larger, more transparent firms. We also show that credit scores and collateral explain a larger variation in the pricing of the foreign banks loans, particularly for larger, more transparent firms. Overall, our findings indicate that domestic and foreign banks can cater to the same clientele using different lending technologies. Domestic banks seem to overcome information asymmetries in credit markets using relationship lending, while foreign banks rely more on transactionbased technologies such as asset-based lending, shorter maturities, and credit scoring models.

But are domestic and foreign banks equally successful? Do alternative lending technologies allow foreign banks to mitigate their distance constraints and profitably lend to the same firms as domestic banks? To answer this question, we study the ex post performance of domestic and foreign bank loans by looking at both the incidence of repayment problems as well as the banks' return on loans, taking into account not only the probability of default but also the loss given default. When comparing loans originated by domestic and foreign banks to the same firm in the same month, we find that loans originated by foreign banks are more likely to have repayments problems, consistent with foreign banks facing higher monitoring costs. This is more pronounced when foreign banks depart from their business model, lending without collateral and/or with longer maturities. Interestingly, we find that foreign banks are not at a disadvantage vis-à-vis domestic banks when lending with collateral and more short-term.

Our paper contributes to the literature on foreign bank entry and is most closely related to Mian (2006). Compared to Mian (2006) who focuses on differences in clienteles of foreign and domestic banks, the first effect of foreign bank entry, we explore differences in lending technologies to a given and identical clientele - the second effect of foreign bank entry. Mian (2006) finds that informational

\footnotetext{
${ }^{9}$ Everything else equal, the takeover increases the geographical and organizational distance between loan officers and the bank's headquarters.
} 
disadvantages pertaining to cultural and geographical distance constraints make foreign banks shy away from smaller, more opaque firms. We additionally find that foreign banks employ contractual mechanisms and loan pricing models to overcome their informational disadvantages vis-à-vis their local competitors. Consistent with theoretical predictions, we find that collateral and maturity can be effective contract design mechanisms that can help foreign banks overcome their informational disadvantages. ${ }^{10}$

Our results also provide an explanation for results in Qian and Strahan (2007) and Haselmann, Pistor and Vig (2010) who find that foreign banks are more sensitive to improvements in collateral laws and creditor rights. The strengthening of formal creditor rights protection is argued to help foreign banks to more effectively use collateral and maturity to overcome cultural and informational barriers. As Haselmann, et al. (2010) put it "legal protection may offer a substitute for cultural and local knowledge." Our findings confirm this explanation. They also provide an explanation for results in Bruno and Hauswald (2014) and Claessens and van Horen (2014) who show that foreign bank entry has a positive effect in countries with more efficient credit information sharing systems and creditor rights protection, consistent with theoretical predictions in Sengupta (2007) and Gormley (2014).

Finally, our paper also relates to an extensive literature on the importance of geographic and cultural distance between borrowers and lenders, which shows that loan contract terms and lending techniques are a critical function of the geographical distance between borrowers and lenders (e.g., Agarwal and Hauswald (2010); Degryse and Ongena (2005); Hauswald and Marquez (2006)), as well as the extent to which borrowers and lenders share cultural, ethnic, religious or socio-economic traits (e.g., Beck, Behr and Madestam (2014); Fisman, Paravisini and Vig (2016)). Our paper also relates to the literature on organizational distance. Several papers have shown that the internal organizational distance within institutions, which can be both a function of ownership and size, matters for lending techniques (e.g., Berger, Miller, Petersen, Rajan and Stein (2005); Mian (2006); Stein (2002)). Overall, these studies

\footnotetext{
${ }^{10}$ While we do not directly focus on the competition between entering foreign and incumbent domestic banks, our results on collateral are consistent with predictions in Sengupta (2007) who shows that lower-cost entrants can use collateral as a screening device to contest the incumbent banks' informational advantage.
} 
find that distance increases inefficiency in credit markets. ${ }^{11}$ We contribute to this literature by showing that contract design and credit scoring can help foreign banks overcome such constraints.

While we cannot make welfare statements, our findings have important repercussions for capital allocation and the role of foreign banks in less developed financial markets. Our findings suggest that foreign banks may only be able to finance larger more transparent firms and/or firms with short-term financing needs and pledgeable assets. If domestic banks cannot redirect their resources and cover the funding needs of the remaining segment of the credit market (e.g., because the quality of the remaining borrower pool is too low), this segment of the market will find it more difficult to obtain credit than in an economy with only domestic banks. Depending on the distribution of firms in the economy, the relative costs of lenders, and the cost of acquiring information, the overall effect may thus be negative (Gormley (2014)). Foreign bank entry in this case could also push existing clients towards more short-term investment strategies and financing of tangible assets, and away from longer-term projects and intangible assets. ${ }^{12}$ Foreign bank entry could also have important implications for firms' funding costs. While firms that can obtain funding from foreign banks may be able to borrow at lower interest rates, the remaining firms will have to pay higher borrowing costs, reflecting the domestic banks' worse borrower pool and market power (see, for example, Dell'Ariccia and Marquez (2004); Gormley (2014); von Thadden (2004)).

The rest of the paper is organized as follows. Section 2 describes the dataset and presents descriptive statistics. Section 3 presents our empirical tests. Section 4 presents our results and several robustness checks, and Section 5 concludes.

\section{Data}

The paper utilizes data from the Central de Información de Riesgos Crediticios (CIRC), the public credit registry of Bolivia, provided by the Bolivian Superintendent of Banks and Financial Entities (SBEF).

\footnotetext{
11 The growing literature on securitization finds similar results. By creating a larger distance between the loan originator and the bearer of a loan's default risk, securitization decreases lenders' incentives to screen and monitor borrowers (e.g., Keys, Mukherjee, Seru and Vig (2010); Rajan, Seru and Vig (2015); Skrastins and Vig (2014)).

${ }^{12}$ Gormley (2010), for example, finds that the entry of foreign banks in India in the 1990s had an overall negative effect on bank lending, which was larger for smaller firms and firms with fewer tangible assets.
} 
Since CIRC's creation in 1989, the SBEF requires all formal (licensed and regulated) financial institutions operating in Bolivia to record information on all loans. We have access to the entire credit registry for the period between January 1998 and December 2003. For each loan, we have information on the origination and maturity dates, the geographical location (region) in which the loan was originated, contract terms, and ex post performance. For each borrower, we have information about their legal structure, industry, bank lending relationships, and whether they have been delinquent or have defaulted on another loan in the recent past. The credit registry is used by the SBEF to monitor and supervise the banking sector. It is also used by banks to better evaluate and monitor their clients. The SBEF requires that some "hard" borrower and loan information is shared among banks to alleviate the otherwise pervasive information asymmetries in Bolivian credit market. After written authorization from a prospective customer, a lender can access the registry and obtain a report that contains information on all outstanding loans of the customer for the previous two months. Entries include the originating bank, loan amount, loan type, value of collateral, value of overdue payments, and the borrower's internal credit rating from the originating bank. Because the available information is limited to the previous two months, important information asymmetries remain. For example, if borrowers pay back an overdue loan, the record resets without any trace of overdue payments on their credit history, which borrowers may exploit strategically. ${ }^{13}$

The data include loans from both commercial banks and nonbank financial institutions (e.g., microfinance institutions, credit unions, mutual societies, and general deposit warehouses). To keep the set of lenders homogenous in terms of financial structure and regulation, we focus exclusively on loans granted by commercial banks to firms. Table 1 provides a list of the 13 commercial banks that were active in Bolivia during the sample period, seven of which are foreign-owned. Following the literature, a bank is considered foreign if at least 50 percent of its equity is owned by foreign investors (see among others Claessens and van Horen (2014)). Four of the foreign banks are branches and three are subsidiaries and, together, they account for $39 \%$ of the commercial banks' loans. Branches are integral parts of the parent

\footnotetext{
${ }^{13}$ As shown in Ioannidou and Ongena (2010) borrowers strategically reset their credit histories before approaching new lenders. The authors also show that controlling for other observable characteristics, overdue payments on past loans - even when repayment is eventually made - are predictive of future repayment problems. Hence, this information, if made available could help banks better evaluate new customers.
} 
company, while subsidiaries are separate legal entities from their parent corporations. As can be observed in Table 1, many of the branches are part of large multinational banks with a relatively small presence in Bolivia. Most foreign banks have a lower cost of deposits than most domestic banks. On average, foreign banks pay 100 basis points lower interest rates on their deposits.

\section{(Insert Table 1 about here)}

For the purposes of our analysis, we focus on commercial loans granted between March 1999 and December 2003. ${ }^{14}$ Commercial loans represent an important segment of the credit markets for which collateral is a negotiated term that is only sometimes present. Among commercial loans, there are several types of contracts in the data, including credit cards, overdrafts, installment loans, single-payment loans, and credit lines. We focus exclusively on installment and single-payment loans and refer to these as "standard debt contracts". These contracts account for $92 \%$ of the total value of commercial loans during the sample period. Of these contracts, $98 \%$ are denominated in U.S. dollars, and we use only these loans in our analysis. To ensure the use of timely information, we only study the originations of "new loan"; renegotiations of previous loans and loans drawn on pre-existing lines of credit are excluded. ${ }^{15}$

All in all, this yields 32,279 loans to 2,672 firms. Table 2 provides summary statistics for these 32,279 loans, which we refer to as the "universe". The stars next to the mean values of domestic bank loans indicate whether the differences between domestic and foreign banks are statistically significant. Throughout the text, ***,**,* indicate significance at the $1 \%, 5 \%$, and $10 \%$ levels, respectively. Table A1 in the Appendix provides detailed definitions for all variables used. The comparison shows striking differences between domestic and foreign bank loans, which might be partly due to different borrower

\footnotetext{
${ }^{14}$ Although we have data as of January 1998, we start our sample in March 1999 since prior to this date the data do not allow us to distinguish between commercial and consumer loans. We use prior information from January 1998 through February 1999 to fill in the history of bank-firm relationships as well as the firms' credit history.

${ }^{15}$ Renegotiations are identified as follows. Banks are required to indicate whether a new loan is a renegotiation of a previous performing or nonperforming loan. We use this information to exclude renegotiation. Loans drawn on preexisting lines of credit, instead, are identified as follows. When a borrower draws on a pre-existing line of credit, a "new loan" appears in the registry with an origination date and contact terms as of the date the bank originated the credit line. Since the date the loan first appears in the registry is subsequent to the origination date, we can identify when a "new loan" is a draw on a pre-existing line of credit and exclude it from our sample.
} 
population and partly due to different loan conditions. ${ }^{16}$ To understand whether differences in contract terms between domestic and foreign bank loans are partly driven by different lending technologies, we eliminate the firm-composition effect by comparing the contract terms of domestic and foreign bank loans to the same firm in the same month. To this end, we restrict our analysis to a sub-sample of loans to firms that received a new loan from at least one foreign and one domestic bank in the same month. The restriction results in a sub-sample of 5,137 loans to 287 firms, which we referred to as "Our Sample". Our sample constitutes $25 \%$ of the total lending amount in the "Universe". Table 2 provides summary statistics for our sample and compares it to the "Universe". Statistics are provided for all loans in the sample as well as for foreign and domestic banks separately. The stars next to each mean value indicate whether it is statistically different from its corresponding value for the "Universe". ${ }^{17}$

(Insert Table 2 about here)

As can be observed in Table 2, our sub-sample draws more heavily on the largest firms. For example, the average loan amount and the outstanding bank debt are significantly higher in our subsample than in the universe. Similarly, sole proprietorships are much less common, while joint stock companies are more frequent. With respect to credit quality results are somewhat mixed. The incidence of past repayment problems is higher in our sub-sample, suggesting riskier firms. With respect to relationship characteristics, we find that firms in our sample have on average longer relationships with their banks but are less likely to have a primary bank, which is expected given that we focus on firms with multiple relationships that tend to be larger. When comparing the terms of domestic and foreign bank loans in our sub-sample, some striking differences emerge. Loans originated by foreign banks are on average smaller by around US $\$ 20,000$ and carry interest rates that are lower by around 86 basis points. Foreign bank loans are also more likely to be secured: $46 \%$ of the foreign bank loans have collateral, while only $19 \%$ of

\footnotetext{
${ }^{16}$ Foreign bank loans are larger, have lower interest rates, are more likely to be secured, and have shorter maturities. Consistent with predictions in Dell'Arricia and Marquez (2004), the clients of foreign banks are, on average, larger. They also tend to be riskier firms with "weaker" bank-lending relationships, consistent with worse credit allocation when competition is more intense (as in Hauswald and Marquez (2010)).

${ }^{17}$ In particular, we construct a specific test statistic with a correspondingly adjusted variance for our mean comparisons. This test statistic accounts for the fact that we compare the means of the entire sample with the means of a sub-sample. The derivation of the statistic and its asymptotic behavior is available upon request.
} 
domestic bank loans do. Their maturities are also shorter by around 3 months. Foreign bank loans are less likely to carry the highest internal rating than domestic bank loans.

In regression analysis, we also present results for sub-samples of smaller and larger firms within the sample of firms that borrow from both domestic and foreign banks in the same month. As information on total firm assets is not available (for confidentiality reasons the firm identities were altered before releasing the data to us), we approximate firm size with total bank debt. ${ }^{18}$ For each firm we calculate the average outstanding debt across all financial institutions over the sample period and divide firms into smaller and larger firms using the median firm's total bank debt (US\$1,014,978). In robustness tests, we also try alternative sample splits using instead the $30^{\text {th }}$ and $70^{\text {th }}$ percentiles of the total bank debt (US\$466,568 and US\$2,329,930, respectively).

\section{Methodology}

We examine whether domestic and foreign banks employ different lending technologies by conducting two sets of empirical specifications. We first test whether loans originated by domestic and foreign banks have systematically different loan contract terms. We compare the incidence of collateral, the maturities, and the interest rates of loans originated by domestic and foreign banks to the same firm in the same month, controlling for several other factors that might explain any observed differences between them. In a second step, we also explore whether domestic and foreign banks use systematically different factors to price their loans. Specifically, we gauge whether the incidence of collateral, the rating of the firm by the bank and the length, depth and breadth of the relationship affect the pricing of loans and whether these relationships vary significantly across banks of different ownership.

To investigate whether domestic and foreign banks impose systematically different loan conditions on their clients we estimate the following model using Ordinary Least Squares (OLS):

\footnotetext{
${ }^{18}$ Using data from the U.S. Survey of Small Business Finances (SSBF), Petersen and Rajan (1994) find that conditional on the existence of institutional debt, the ratio of bank debt to total debt does not significantly vary with firm size. For firms with less than $\$ 15,000$ in total assets, this ratio is equal to 51 percent, while for firms with more than $\$ 2,000,000$ in total assets the ratio equals 62 percent. Since capital markets are less developed in Bolivia than in the US, this ratio may vary even less, such that total bank debt is most likely highly correlated with firm size.
} 
where $i, j, k, t$ index loans, firms, banks, and time (month-year) of loan origination, respectively. For LoanContract ${ }_{i j k}$ we employ three dependent variables: (i) a dummy indicating whether the loan contract includes the pledge of collateral, (ii) the natural logarithm of one plus the number of months between loan origination and maturity, and (iii) the loan interest rate minus the rate on US Treasury securities of comparable maturity at loan origination. Our key explanatory variable, ForeignBank $k_{k}$, is a dummy variable that indicates whether the originating bank is foreign-owned. This variable is time invariant as during the sample period there are no changes in bank ownership. In a robustness test, however, we extend our sample period backwards to study the takeover of a domestic bank by foreign investors.

Our set of control variables includes several indicators that control for firm and other loan characteristics as well as firm-month fixed effects. The vector Firm $_{j k t}$ is comprised of firm characteristics that vary within the same month across banks. This includes the firm's internal rating at each bank as well as indicators of the strength of the bank-firm lending relationship at the time of the loan origination. For ratings, we include two dummy variables: $R a t i n g 2_{j k t}$ and Rating $3 \& 4_{j k t}$. Rating $2_{j k t}$ equals one if the firm's rating equals 2 , and equals zero otherwise, while Rating $3 \& 4_{j k t}$ equals one if the firm's rating equals either 3 or 4 , and equals zero otherwise. ${ }^{19}$ ( $\operatorname{Rating} l_{j k t}$, which indicates the best rating, is the omitted category.) These ratings refer both to "hard" information about firms as well as "hardened" soft or subjective information collected by the loan officer in the screening process. They can vary across banks for different reasons, including different soft and hard information sets and different interpretation of available information. To gauge the intensity of a bank-firm relationship we employ three variables: RelDuration ${ }_{j k t}$, RelScope $_{j k t}$, and PrimaryBank Prt. RelDuration $_{j k t}$ is equal to the natural logarithm of one plus the number of months we observe the bank-firm pair in a credit relationship; ${ }^{20} \operatorname{RelScope}_{j k t}$ is a dummy variable indicating

\footnotetext{
${ }^{19}$ To gain statistical power, ratings 3 and 4 are merged into one dummy variable given the small number of loans with such ratings (see descriptive statistics in Table 2).

${ }^{20}$ RelDuration_Square $_{j k}$ (i.e., the square of RelDuration ${ }_{j k}$ ) is also sometimes included in our specifications. For our baseline results, we estimated the regressions with and without the square term to test for the possibility of a nonlinear relationship. If the square term is found to be statistically significant, we report the regression results with the square term. If not, we report the results without the square term.
} 
whether the firm has other credit products from the bank (e.g., credit cards, overdrafts, mortgages); and PrimaryBank $_{j k t}$ indicates whether the bank accounts for more than 50 percent of the firm's bank debt.

The vector Loan $_{i j k t}$ includes other loan characteristics such as Installment ${ }_{i j k t}$ and LoanAmount ${ }_{i j k}$. Installment $_{i j k t}$ is a dummy variable indicating whether the loan is an installment loan as opposed to a single-payment loan and LoanAmount $t_{j k}$ is measured as the natural logarithm of one plus the amount of loan proceeds at origination in US dollars. In the interest rate regressions, we also include Collateral $_{i j k t}$, and Maturity $_{i j k t}$, effectively assuming that these contract terms are determined prior to the loan interest rate, consistent with the maintained assumption in most of the extant empirical literature in banking (e.g., Berger and Udell (1995); Degryse and Ongena (2005); Elsas and Krahnen (1998); Harhoff and Körting (1998); Ortiz-Molina and Penas (2008)). Since each of these other contract terms may be simultaneously determined with the dependent variable and is thus potentially endogenous, we first estimate our models without other contract terms among the controls. In robustness tests presented below, we also employ a matching technique as in Ioannidou and Ongena (2010) and an instrumental variable (IV) approach following Bharath, Dahiya, Saunders and Srinivasan (2011).

Finally, $\eta_{j} \times \gamma_{t}$, are firm fixed effects, $\eta_{j}$, interacted with time (month-year) fixed effects, $\gamma_{t}$, to account for observable and unobservable firm characteristics. Our estimates are thus obtained using only within firm-month variation for the sub-sample of firms that borrow from both domestic and foreign banks in the same month. This is the reason for which we do not include time-invariant firm characteristics. In addition to estimating the above regression for the whole sample, we also estimate it separately for firms of different size using their total outstanding bank debt as a proxy of their size. We use OLS for all three dependent variables. For collateral, we use OLS instead of non-linear Probit or Logit models as we would otherwise lose a large number of firm-month clusters with no variation in collateral across different banks for the same firm within the same month. ${ }^{21}$ In all cases, the standard errors are clustered at the firm level

\footnotetext{
${ }^{21}$ Because of the large number of fixed effects in our model relative to the smaller number of periods for which a borrower is observed, a non-linear model could also give inconsistent estimates; this is known as the "incidental parameter problem" (see, for example, discussion in Cameron and Trivedi (2005, pp. 726-727).
} 
to account for the possibility that the observations of the same firm across different loans, bank, and time are correlated with each other. ${ }^{22}$

Given our set of controls variables, a statistically significant $\beta_{1}$ would indicate that the probability of collateral, the maturity and the interest rates on domestic and foreign bank loans to the same firm in the same month are systematically different, even after controlling for possible differences in banks' credit risk assessment, the strength of the bank-firm lending relationship, as well as other loan contract terms. If foreign banks are using collateral and maturity to mitigate information asymmetries and agency conflicts, we would expect that they will be more likely to require collateral and lend at shorter maturities than domestics banks, even when lending to the same customers.

Next, we examine whether the factors that explain the variation in the loan interest rates to the same firm in the same month vary systematically between domestic and foreign banks by introducing interactions between the foreign bank dummy and our control variables:

$$
\begin{aligned}
\text { LoanSpread }_{i j k t}= & \alpha_{2}+\gamma_{1} \text { ForeignBank }_{k}+\gamma_{2} \text { Firm }_{j k t}+\gamma_{3} \text { Loan }_{i j k t}+ \\
& \gamma_{4} \text { ForeignBank }_{k} \times \text { Firm }_{j k t}+\gamma_{5} \text { ForeignBank }_{k} \times \text { Loan }_{i j k t}+\eta_{j} \times \gamma_{t}+\varepsilon_{i j k t}
\end{aligned}
$$

where $i, j, k, t$ index loans, firms, banks, and time (month-year), respectively. All variables are defined as in equation (1). In this case, our focus is on the coefficients of the interaction terms, which indicate whether internal credit ratings, relationship strength, and other loan contract terms are used differently by domestic and foreign banks when pricing their loans. Since the coefficients are again estimated using only within firm-month variation such differences would point to the use of different lending technologies. If, for example, foreign banks rely more on transaction-based technologies, such as credit scoring and assetbased finance, we would expect credit ratings and collateral to play a more prominent role in foreign banks' pricing. Similarly, if domestic banks rely more on relationship lending, we expect the relationship

\footnotetext{
${ }^{22}$ In unreported sensitivity analyses, we also test the robustness of our results to alternative clustering assumptions. Standard errors may be correlated at the bank level if bank-level shocks affect all loans given by a specific bank. We confirm our results when clustering standard errors at both the bank level and at the bank-year and firm level.
} 
variables to be more important for the domestic banks' pricing. As in the case of regression (1), the model is estimated using OLS clustering the error terms at the firm level.

\section{Results}

\subsection{Bank ownership and loan contract terms}

The results in Table 3 show that foreign bank loans are more likely to have collateral and are more shortterm than domestic bank loans. Columns I to V present results of the collateral regressions and columns VI to $\mathrm{X}$ present results of the maturity regressions. As discussed earlier, both the collateral and the maturity regressions are estimated using OLS. In all cases, we include firm $\times$ time fixed effects and investigate whether the likelihood of pledging collateral and the maturity of loans vary systematically between domestic and foreign banks, even when lending to the same firm in the same month.

(Insert Table 3 about here)

As can be observed in columns I to III, foreign bank loans are between 27 and 28 percentage points more likely to have collateral; a large effect given that only $33 \%$ of all loan contracts in our sample include collateral. We also find that loans to firms with a rating of 2 rather than 1 are more likely to have collateral. Loans to firms with longer relationships and a primary bank status with a bank are less likely to have collateral. ${ }^{23}$ These results support previous empirical findings in the relationship lending literature (e.g., Berger and Udell (1995); Elsas and Krahnen (1998); Harhoff and Körting (1998); Machauer and Weber (1998); Petersen and Rajan (1994)). Controlling for other contract terms has no material effect on our findings. The coefficients of the other contract terms indicate that larger loans are more likely to have collateral. In columns IV and V, we also split the sample into smaller and larger firms and confirm the results for both groups. The results in columns VI-VIII show that loans granted by foreign banks have maturities that are between $19 \%$ and $27 \%$ shorter than loans granted by domestic banks. At the average maturity of nine months, this implies a difference of two to three months. With respect to our control

23 Adding the square of RelDuration ${ }_{j k}$ in the specification results in statistically insignificant coefficients for RelDuration $_{j k}$ and its square term. 
variables, we find that variation in credit ratings is not significantly associated with variation in loan maturities. Relationship characteristics, on the other hand, seem to play an important role. Loans to firms with longer relationships (more than eleven months) and a primary bank status with a bank have longer maturities, consistent with the relationship lending literature. Additional products, on the other hand, are associated with shorter maturities, although this effect is significant only at the $10 \%$ level. Controlling for other contract terms results in a larger absolute coefficient for Foreign, suggesting that loan maturity is correlated with Installment and Loan Amount. The coefficients of the other contract terms indicate that installment loans and loans with larger loan amounts have longer maturities. Dividing our sample into smaller and larger firms in columns IX and X, confirms again our findings for both sets of firms. ${ }^{24}$

The results in Table 4 show that foreign banks charge the same firm in the same month about 89 to 107 basis points lower interest rates than domestic banks, confirming the difference reported in the descriptive statistics. Relative to the interest rate of domestic bank loans, these estimates imply a $9 \%$ discount. As can be observed in column I, loans originated by foreign banks carry on average 89 basis points lower interest rates than loans originated by domestic banks. This difference is statistically significant at the $1 \%$ level and remains unchanged when we additionally control for possible differences in credit ratings and the strength of the bank-firm relationships in column II. Adding other contract terms in column III reveals that collateralized loans and loans with longer maturities have on average lower interest rates. The negative coefficient of collateral is consistent with the theoretical literature on the role of collateral in debt contracts. ${ }^{25}$ The negative coefficient on maturity is consistent with lower risk firms

\footnotetext{
${ }^{24} \mathrm{We}$ also explore whether collateral and maturity are complements or substitutes as mechanisms to overcome information asymmetries and agency problems. We split domestic and foreign bank loans within our sample into four groups according to whether (i) they are secured or unsecured and (ii) have maturities below or above the median maturity in our sample. For foreign bank loans, we find that $65 \%$ of their secured loans have a below-median maturity, thus two-thirds of secured foreign bank loans also have a short maturity. On the other hand, among unsecured foreign banks loans, the distribution between below-median $(52 \%)$ and above-median $(48 \%)$ loans is much more even. There is no comparable difference for domestic bank loans. In summary, foreign banks seem to use collateral and short maturity as complements rather than substitutes.

${ }^{25}$ The lower interest rates on secured loans are consistent with both the ex ante and the ex post theories of collateral. Under the ex-ante theories unobservably safer borrowers are more likely to pledge collateral to signal their quality and receive lower interest rates (e.g., Bester $(1985,1987))$. Under the ex post theories, observably riskier borrowers are more likely to be required to pledge collateral to mitigates ex post frictions such as moral hazard and bank losses in the default (e.g., Boot, et al. (1991); Boot and Thakor (1994); Holmstrom and Tirole (1997)). Hence, conditioning on borrower risk, the ex post theories are also consistent with lower interest rates for secured loans.
} 
(projects) obtaining loans with longer maturities. Controlling for other contract terms in column III does not qualitatively change the foreign bank result, but the estimated coefficient becomes bigger in absolute terms: it increases from -89 to -107 basis points, suggesting that loan interest rates are correlated with other contract terms and bank ownership. With respect to other control variables, we find that lower credit ratings are associated with significantly higher interest rates, while stronger lending relationships are typically associated with lower interest rates. Dividing the sample into smaller and larger firms confirms again our findings for both groups (columns IV and V). The estimated difference is 113 basis points for larger firms and 96 basis points for smaller firms. ${ }^{26}$ The remaining columns of Table 4 show that differences in market shares and funding costs do not explain the interest rate differential. ${ }^{27}$ ForeignBank continues to enter with the same economic and statistical significance as before, while neither funding costs nor market shares enter significantly. ${ }^{28}$

\section{(Insert Table 4 about here)}

Overall, our findings suggest that foreign banks are more likely to require collateral, grant loans with shorter maturities, and charge lower interest rates, even when lending to the same firm in the same month and this holds for both smaller and larger firms. ${ }^{29}$ There is thus a clear trade-off for firms when taking out loans from both domestic and foreign banks, which may explain why firms maintain active relationships with both domestic and foreign banks. These findings are consistent with our first hypothesis that foreign banks use contract terms to help overcome distance-related information asymmetries. There could be, however, concerns about omitted variable biases, alternative explanations, or estimation techniques. In the

\footnotetext{
${ }^{26}$ Similar results are obtained if we instead split firms using the $30^{\text {th }}$ and $70^{\text {th }}$ percentiles of the total outstanding bank debt with a 113 basis point estimated difference for larger firms and 92 basis points for smaller firms. The somewhat larger discounts for larger firms may be capturing economies of scales and smaller average costs of screening and monitoring larger loans and firms. This would be consistent with the presence of important fixed costs, for example.

${ }^{27}$ Table 1 shows that foreign banks have significantly lower funding costs and many of them have smaller market shares than domestic banks. These differences can in principle drive the interest rate differential that we find. Lower funding costs can allow foreign banks to charge lower loan interest rates. Our results admittedly cannot control for access to internal capital markets by foreign banks. Higher market shares may be associated with higher or lower interest rates depending on whether market power or economies of scale effects dominate.

${ }^{28}$ In unreported robustness tests, we also control for the cost of deposits in the maturity and collateral regressions. Like for the interest rate regressions, the coefficients of ForeignBank are not affected.

${ }^{29}$ In unreported robustness tests, we also study whether there are differences in the loan amounts of domestic and foreign bank loans using similar specifications, but find no differences.
} 
next section, we subject our results to several robustness tests to address these concerns. Additional robustness tests, regarding sample selection are presented in Section 4.6 at the end of the paper.

\subsection{Robustness Checks}

First, we examine whether unobserved differences on the purpose of the loan are driving our results by exploiting exogenous (to the firm) variation in distance-related information asymmetries. We exploit exogenous (to the firm) variation in bank ownership using the takeover of the domestic Banco Boliviano Americano (BBA) by the foreign Banco de Crédito de Bolivia (BCR) in May 1999 - the only takeover event in our sample period. ${ }^{30}$ The takeover of a domestic bank by a foreign bank is expected to increase distance-related information constraints as it increases the geographical and organizational distance between the bank's headquarters and the local branches and the borrowing firms. Greater organizational distance may add more layers in the credit allocation decision, favoring the use of more standardized process in evaluating and managing risks such as collateral and maturity. To perform this test, we identify all loans from the acquired bank (BBA) in the year prior to the merger. We then trace any loans that these firms received from the acquiring bank $(\mathrm{BCR})$ in the three years following the acquisition, dropping all loans to firms that were already customers of BCR prior to the acquisition. ${ }^{31}$ This leaves us with 401 loans, which we refer to as the treated group. To control for changes in the macroeconomic environment and the banking system over the comparison period, we use loans to the same firms by their other (nontaken-over) banks before and after the acquisition as a control group. This leaves us with 766 loans, which we refer to as the control group. Using these two groups, we estimate:

$$
\text { LoanContract }_{i j k t}=\alpha_{3}+\delta_{1} \text { Treated }_{i j k t}+\delta_{2} \text { Treated }_{i j k t} \times \text { After }_{t}+\delta_{3} \text { After }_{t}
$$

\footnotetext{
${ }^{30}$ At the beginning of the sample period, one more bank changed ownership status. In particular, Banco Solidario's ownership changed from domestic to foreign-owned when one of its three main investors moved outside Bolivia, making this a less clear case.

${ }^{31}$ For this exercise we extend the sample period backwards to April 1998. A disadvantage of using data prior to 1999 is that we cannot distinguish between commercial and consumer credit. Using a difference-in-difference analysis with borrower fixed effects, $\eta_{j}$, allows us to mitigate this problem.
} 


$$
+\delta_{4} \text { Firm }_{j k t}+\delta_{5} \operatorname{Loan}_{i j k}+\delta_{6} \text { Bank }_{k t}+\eta_{j}+\varepsilon_{i j k t}
$$

where Treated $_{i j k t}$ equals one for all loans in the treated group, and equals zero for all loans in the control group. After $r_{t}$ equals one for all loans originated after May 1999, and equals zero for all loans originated prior to May 1999. Treated ${ }_{i j k t} \times$ After $_{t}$ equals one for all loans in the treated group after the takeover in May 1999. The reference group is loans by (non-taken-over) banks to the same firms prior to May 1999. Bank $k_{k t}$ includes bank controls such as bank size, market share, and cost of deposits. All other variables are defined as in equation (1). The inclusion of firm fixed effects, $\eta_{j}$, in this specification is possible as the same firm has loans in both the treated and the control group. The coefficient of interest is $\delta_{2}$ which measures the systematic changes in the contract terms of the treated group before and after the acquisition relative to the control group. Results are reported in columns I-III of Table 5. We find that relative to the control group, the treated group experienced a large and significant increase in the likelihood of collateral and a drop in maturity. We find no significant changes in interest rates. Relative to the control group, the likelihood of collateral for the treated group increased by 28.8 percentage points, while maturity decreased by around 4.3 months. Similar results are obtained if After $_{t}$ is replaced with time fixed effects (columns IV-VI). Our findings in Table 5 show that exogenous (to the firm) changes in bank ownership have similar effects on collateral and maturity as those documented earlier and suggest that these differences are unlikely to be due to unobserved heterogeneity on the purpose of the loan.

(Insert Table 5 about here)

Next, we explore whether differences in collateral, maturity, and interest rates between domestic and foreign banks are due to an alternative bank "fixed-effect hypothesis". It is possible, for example, that the banks that happen to be foreign in Bolivia have different lending styles independent of their location; this would imply that they also behave similarly as in Bolivia regardless of where they are, including in their own home countries. In order to test this, we focus on two foreign banks in our sample - Banco do Brasil and Citibank - for which we have loan-level data for the respective home country. In the case of Citibank, we use Dealscan data on syndicated loans to compare the incidence of collateral, maturity and all-in-spread-drawn of Citibank loans to those of other domestic banks in the United States in a regression 
set-up similar to that for our Bolivian sample. ${ }^{32}$ Relative to other domestic banks, the bank fixed-effect hypothesis predicts a positive coefficient on collateral, a negative coefficient on maturity, and a negative coefficient on the spread (i.e., similar results as in Bolivia). Our results - available on request - do not show any significant differences in collateral, maturity and interest spread between Citibank loans and loans by other domestic banks in the United States, even when given to the same firms in the same quarter. In a second exercise, we compare the loan conditionality of the largest three Brazilian government-owned banks (one of which is Banco do Brasil) ${ }^{33}$ to the loan conditionality of other domestic banks in Brazil using a regression set-up similar to that of our Bolivian credit registry data. Our findingsavailable on request - do not provide evidence in line with the bank-fixed effect hypothesis. Compared to other domestic banks, two of the three government-owned banks are less likely to demand collateral and give longer maturity loans. Results with respect to loan spreads are not consistent across specifications.

We also contrasted the behavior of Citibank and Banco do Brasil to other foreign banks in their respective home markets. For Citibank, we find again no systematic differences in contract terms. For the Brazilian exercise, we find that foreign banks in Brazil are more likely require collateral and shorter maturities than two out of the three domestic banks. For loan spreads, results were again inconsistent across specifications. The results for Brazil - another country with opaque credit markets and a weak institutional framework where the foreign banks' distance constraints may be more binding - mirror our key findings for collateral and maturity in Bolivia. The absence of differences for the United States is consistent with limited information barriers. This may be due to a combination of strong and more transparent institutional framework and the use of syndicated loan data that draw heavily from larger, more transparent firms. Foreign banks may be still disadvantaged in more opaque segments of the U.S. market. Overall, these findings confirm that the differences between foreign and domestic bank-loans in Bolivia are explained by distance-related information asymmetries, which loom large in Bolivia and to some extent in Brazil, but much less in the syndicated loan market in the United States.

\footnotetext{
${ }^{32}$ The sample is constructed following Berg, Saunders and Steffen (2016). We are grateful to the authors for sharing their data and programs.

${ }^{33}$ For confidentiality reasons, we could not get identifying information for individual banks.
} 
Next, we subject our results to two robustness tests with respect to our estimation technique. First, we investigate the robustness of our findings using a matching technique instead of a regression analysis. Matching is nonparametric and thus imposes no functional form restrictions on the way the matching variables relate to the dependent variable. Although matching does not solve omitted variable issues arising from the joint determination of contract terms, it could help mitigate such concerns as it does not incorporate any information from outside the overlap region (i.e., it only uses observations and variation that satisfy the matching criteria). Regressions, instead, use variation across all observations and control for the average effect of any control variable on the dependent variable in a linear fashion. ${ }^{34}$ We match using a procedure similar to Ioannidou and Ongena (2010) and Degryse, Ioannidou and von Schedvin (2016), matching on each variable individually allowing for replacement and multiple neighbors. For discrete variables, we use exact matching. For continuous variables, we use caliber matching using a 0.5 standard deviation radius for each of our matching variables. Table 6 reports our findings. In column I, we match on firm identity and month of loan origination. In column II, we additionally match on ratings and relationship characteristics. In column III, we also match on other contract terms as in Tables 3 and 4 . We present results that correspond to our specifications in Tables 3 and 4. As can be observed in Table 6, in all cases we find results that are qualitatively similar to those presented earlier.

(Insert Table 6 about here)

Second, we re-estimate our models allowing collateral, maturity, and loan contract terms to be jointly determined using an IV framework as in Bharath, et al. (2011). Following Bharath, et al. (2011), we assume that the loan interest rate is set last; after all other contract terms are determined. Collateral and maturity instead are assumed to be set simultaneously and prior to the loan interest rate. This implies that collateral and maturity influence each other (a bidirectional relationship), while the loan interest rate spread is affected by collateral and maturity but not vice versa (a unidirectional relationship). We estimate the resulting system of equations using the two-stage-least squares (2SLS). Following Bharath, et al. (2011), we use a dummy for industries with fewer tangible assets as an instrument for collateral, a dummy

\footnotetext{
${ }^{34}$ See, for example, discussions in Ioannidou and Ongena (2010) and Roberts and Whited (2012).
} 
for regulated industries for maturity, and the average loan spread of all banks over the previous six months for loan spreads. ${ }^{35,36}$ The IV approach necessitates two modifications to our benchmark models. First, we cannot include firm $\times$ time fixed effects since the instruments do not vary in a given month within a firm. Second, the bidirectional relationship between collateral and maturity requires adding maturity in the collateral equation and collateral in the maturity equation. To be able to compare the IV estimates to estimates obtained ignoring the joint determination of contract terms, we re-estimate our models adopting these modifications. Results are reported in Table 7 (columns (a)). The coefficients of the foreign bank dummy are very similar to those reported earlier (see columns III and VIII of Table 3 and column III of Table 4). ${ }^{37}$ In the second set of specifications (columns (b)), we add the instrument of the dependent variable as an additional explanatory variable in the specifications to see if it is statistically significant. In all cases, the instruments are found to be statistically significant. In the third set of columns (columns (c)), we report the second-stage results of the IV model. The results with respect to collateral and maturity are qualitatively similar to columns (a). In terms of size, the IV estimates for collateral are very similar to those in column (a). As can be observed in Table 7, the IV estimates for the foreign bank dummy in both the collateral and maturity regressions are similar to those obtained when ignoring the joint determination of loan contract terms (the marginal effect in the collateral equation is 0.321 ). For the loan spread, the foreign bank effect loses its economic and statistical significance, consistent with results from the takeover exercise. This indicates that the estimated loan rate discounts of foreign banks are due to the systematically different other loan characteristics.

(Insert Table 7 about here)

\footnotetext{
${ }^{35}$ See Bharath, et al. (2011) for an extensive discussion on the reasoning behind their choice of instruments in relation to the extant theoretical and empirical literature on debt maturity, collateral, and loan interest rates. To distinguish between regulated and non-regulated industries in Bolivia we use the Sectoral Regulatory System Law (Law 1600) introduced in 1994.

${ }^{36}$ Since collateral is a discrete variable, we use the fitted values from a first stage logit equation for collateral as an instrument for collateral (see Bharath, et al. (2011) and Wooldridge (2002)).

${ }^{37}$ The marginal effect of the foreign bank coefficient in the collateral equation is 0.326 , thus similar to the OLS estimates.
} 
To assess the relevance and validity of our instruments we perform a variety of tests, reported at the bottom of Table 7. The two key criteria that an instrument must meet are relevance (instrument is correlated with endogenous variable) and validity (instrument affects the dependent variable only through the endogenous variable). The first set of tests assesses whether the instruments used are relevant using the Cragg-Donald test statistic. ${ }^{38}$ In all cases, the reported statistics exceed the critical values reported by Stock and Yogo (2005), implying that our instruments are relevant. The Kleibergen-Paap rk LM statistics - another test of relevance - yield similar conclusions. ${ }^{39}$ Tests of the instrument's validity can only be calculated if the number of instruments is higher than the number of endogenous variables so that the system of equations is overidentified. To perform a validity test, we employ two additional instruments. We use an indicator variable for sole proprietorship as an additional instrument for collateral as in Bellucci, Borisov, Giombini and Zazzaro (2015) and the term spread as an additional instrument for maturity as in Bharath, et al. (2011). Results and tests are reported in the fourth column for each contract term (columns (d)) and are similar to those obtained earlier in columns (c). In all cases, the Hansen's Jstatistic fails to reject the null hypothesis, implying that our instruments are relevant and valid.

All in all, our robustness tests confirm that foreign banks are more likely to require collateral and grant loans with shorter maturities even when lending to the same firm in the same month. Differences between domestic and foreign bank loans with respect to interest rates are not robust. Unobserved heterogeneity on the purpose of the loan and other contract terms are partly driving these differences.

\subsection{Bank ownership and loan pricing}

\footnotetext{
${ }^{38}$ For an IV probit with clustered standard errors there is no corresponding test for weak instruments. A test exists if standard errors are not clustered (the Anderson and Rubin (1949) test statistics based on work by Finlay and Magnusson (2009)). In unreported specifications, we re-estimate our model without clustering the standard errors and perform this test. We obtain a Chi-square $=16.08$ and $\mathrm{p}$-value $=0$, rejecting the null that the instrument for collateral is weak.

${ }^{39}$ We use the Kleibergen-Paap rk LM statistic (Kleibergen and Paap (2006)), instead of Anderson's LR statistic used in Bharath, et al. (2011), because it is robust to non i.i.d. errors (we cluster standard errors at the firm-level in our case).
} 
We now turn to the second empirical model to gauge differences between foreign and domestic banks in their loan pricing. In particular, Table 8 reports results for the fully interacted model of equation (2). Column I shows the estimated coefficients for domestic banks, column II reports the coefficients of the interaction terms with the foreign bank dummy (i.e., the difference of foreign banks relative to domestic banks), and column III shows the cumulative coefficients for foreign banks. In columns IV-VI and VII-IX, we also report the corresponding specifications for smaller and larger firms, respectively. ${ }^{40}$

\section{(Insert Table 8 about here)}

The results in Table 8 show significant differences between domestic and foreign banks in the pricing of their loans even when lending to the same firm in the same month. The results in columns I to III reveal that only foreign banks use credit ratings to price their loans. Specifically, we find that the variation in credit ratings is significantly related to the variation in interest rates in the case of foreign but not in the case of domestic banks. ${ }^{41}$ Moreover, as can be observed in columns VI and IX, foreign banks use credit ratings mainly for the pricing of their loans to larger firms. ${ }^{42}$ Domestic banks instead seem to base their pricing on the strength of their lending relationship with the firm, particularly for smaller firms. As can be observed in column IV, smaller firms with longer relationships above seven months and a primary bank status with a domestic bank are charged lower interest rates. ${ }^{43}$ These effects are less pronounced for larger firms. While the coefficient of the primary bank status in column VII remains

\footnotetext{
${ }^{40}$ As before, smaller and larger firms are defined using the median firm's total outstanding bank debt as a threshold as in Table 3. However, similar results are obtained if we use the $30^{\text {th }}$ and the $70^{\text {th }}$ percentiles instead.

${ }^{41}$ As this finding might be due to the lower variation in credit ratings by domestic banks, we re-ran these regressions, using a standardized credit rating variable, where each rating is expressed as the difference between the actual rating and the originating bank's average rating divided by the standard deviation in the originating bank's rating. The results using these standardized credit ratings, available on request, confirm our findings.

${ }^{42}$ In unreported results, we re-estimate our specifications of equation (2) after replacing the credit ratings with a dummy variable indicating whether the firm had observable defaults or repayment problems as in following Berger, Frame and Ioannidou (2011). This variable is not found to be statistically significant, suggesting that credit ratings contain additional (soft and more forward looking) information about the firm than mere past (non) performance, consistent with results in Agarwal and Hauswald (2010). This might be explained by the fact that by looking at a sample of firms that get multiple loans from multiple banks in a given month we focus on some of the larger firms in the sample. For example, re-estimating the interest rate regression for the entire sample, yields a positive and significant coefficient for the past nonperformance variable.

${ }^{43}$ The positive coefficient on relationship length and the negative coefficient on its square imply that interest rates decrease in relationship length, when Rel Duration is larger than 2.08, corresponding to a relationship length of 7 months. The negative relationship between relationship length and interest rates turns significant at 26 months.
} 
statistically significant, the size of the coefficient is much smaller (in absolute terms) and relationships length is not found to matter for larger firms. With the exception of additional products from the bank (Rel Scope), which are positively related to interest rates, none of the relationship characteristics is found to explain the interest rate variation of foreign bank loans to larger firms in columns VI and IX. Turning to other contract terms, we observe that collateral pledges are associated with lower interest rates for larger firms in the case of foreign banks, but not in the case of domestic banks. Installment loans are charged higher interest rates by both domestic and foreign banks, but only in the case of larger firms. While variation in the loan amount is not significantly associated with variation in interest rates, higher maturity loans attract lower interest rates, both from domestic and foreign banks.

Table 9 provides additional insights on the extent to which "hard" or hardened information explain variation in the pricing of foreign and domestic bank loans. Following Rajan, et al. (2015), we estimate a separate pricing model for foreign and domestic bank loans using credit ratings and collateral as the only explanatory variables and compare the resulting $R$-squares for domestic and foreign bank loans. If foreign banks rely mostly on hard or hardened information while domestic banks rely in addition on soft information stemming from the depth and breadth of the relationship with borrowers, then credit ratings and collateral should explain a higher share of variation in interest rates in the case of foreign than in the case of domestic banks. We also estimate this model separately for smaller and larger firms. As can be observed in columns I and II of Table 9, ratings and collateral explain about $10 \%$ of the interest rate variation of foreign bank loans and a mere $2 \%$ of the interest rate variation of domestic bank loans. Reestimating these models for smaller and larger firms separately confirms these results for both smaller and larger firms and shows that the difference in R-squares between foreign and domestic banks is more pronounced for larger firms. For smaller firms, the foreign banks' $R$-square is about 76 percent higher than that of domestic banks, while it is 574 percent higher for larger firms.

Overall, these findings suggest that hard or hardened information such as credit scores and collateral play a much more important role in the pricing of foreign bank loans, particularly for larger firms. This is not surprising as larger firms are more likely to have collateral and more information may be available on them, allowing foreign banks a more meaningful use of credit scoring models. Nevertheless, 
as can be observed in Table 9 significant heterogeneity remains consistent with the extant literature on the pricing of commercial loans (see, for example, Cerqueiro, Degryse and Ongena (2011)).

(Insert Table 9 about here)

All in all, these findings are consistent with our second hypothesis that foreign banks use transaction-based technologies, such as credit scoring and asset-based finance that rely on hard or hardened information, especially when lending to larger firms. Domestic banks instead engage more in relationship lending, especially in the case of smaller firms. These results are consistent with the idea that domestic and foreign banks cater to the same customers using different lending technologies that better exploit their comparative advantages vis-à-vis their local competitors (as suggested, among others, by Berger and Udell (2006); De la Torre, et al. (2010); Sengupta (2007)). Our findings also highlight the need to control for differences in the clienteles of domestic and foreign banks as the use of different lending technologies for firms of different size could produce similar but misleading results.

\subsection{What drives distance-related information constraints?}

In this section, we present additional results exploiting cross-sectional variation on distance constraints using a bank's mode of entry in Bolivia and time since entry or since becoming foreign owned. These results help shed light on the possible sources of distance constraints of foreign banks and are related to our third hypothesis stated in the Introduction that the use of contract terms to overcome information asymmetries should increase in the distance within the bank or between the bank and the borrower.

We first distinguish foreign banks into branches and subsidiaries. During the sample period, Bolivia had four foreign branches and three foreign subsidiaries. All else equal, we expect distance-related information constraints to be more pronounced for foreign branches than foreign subsidiaries. Branches are integral parts of their parent company, while subsidiaries are separate legal entities with greater operational autonomy from their parent companies. Hence, while in the case of subsidiaries most lending decisions may be delegated to local management, in the case of branches, it is likely that there will be more centralization resulting in greater geographical and organizational distance and greater reliance on "hard" information (see, among others e.g., Aghion and Tirole (1997); Mian (2006); Skrastins and Vig (2014); Stein (2002)). Information asymmetries are also expected to be stronger for branches of foreign 
banks than subsidiaries. Subsidiaries are former domestic banks that may have better knowledge of the country (local economy, corporate culture, legal framework, and institutions) than branches of foreign multinational banks. ${ }^{44}$ We thus expect that the differences between domestic and foreign banks in their lending technologies are more pronounced for foreign branches than for foreign subsidiaries. ${ }^{45}$

To investigate this possibility, in Table 10, Panel A we re-estimate a slightly modified version of equation (1), in which the foreign bank dummy is split into its two components and the sample is restricted to firms that obtained at least one loan from a domestic bank, a foreign subsidiary, and a foreign branch in the same month. The resulting sample includes 689 loans to 30 unique firms. Consistent with our expectations we find that the differences documented earlier between domestic and foreign banks with respect to collateral and maturity are more pronounced for foreign branches than foreign subsidiaries. Results with respect to maturity are contrary to expectations. We find that while foreign subsidiaries have shorter maturity loans relative to domestic banks, foreign branches do not. Given the small sample in Panel A, in Panel B we relax the restriction that firms must be borrowing from all three types of banks in the same month and consider a sample of firms borrowing from the three types of banks at any point during the sample period, resulting in a sample of 7,040 loans to 117 firms. Firm-month fixed effects are thus replaced with firm and time fixed effects. Results are similar to those in Panel A.

(Insert Table 10 about here)

Overall, the results in Panels A and B indicate that while differences between domestic and foreign banks with respect to collateral and interest rates are more pronounced for foreign branches rather than foreign subsidiaries as expected. The opposite, however, seems to hold for maturity. This is puzzling as theory offers no guidance as to why collateral or maturity may be used differentially by foreign branches and subsidiaries. Results in Panel C indicated that failing to account for time since entry or since becoming foreign owned, may confound comparisons between branches and subsidiaries. In Panel $\mathrm{C}$ we

\footnotetext{
${ }^{44}$ See, among others, Bruno and Hauswald (2014), Claessens and van Horen (2014), Giannetti and Yafeh (2012), Gormley (2014), and Mian (2006).

${ }^{45}$ The literature also suggests that branches and subsidiaries follow different business models. As discussed in Cerutti, Dell'Ariccia and Martínez Pería (2007) foreign branches are smaller operations focusing on small segments of the overall market such as wholesale operations and investment banking, with less focus on retail operations.
} 
allow for interactions between foreign branches and foreign subsidiaries with time since entry and time since becoming foreign owned. The impact of time on these two types of foreign banks may be very different. Branches may become more like domestic banks as time since entry passes and become more accustomed with the local economy, its culture, and institutions (i.e., informational disadvantages vis-à-vis the domestic banks may decrease over time). Subsidiaries instead may become more like foreign banks as time passes. All else equal, the takeover increases the geographical and organizational distance between loan officers and the bank's headquarters. After the takeover, foreign banks may thus begin adjusting their lending policies to their new structure, becoming more like foreign banks as time passes.

Results in Panel C confirm these predictions. ${ }^{46} \mathrm{We}$ find that as time since entry increases, foreign branches become more like domestic banks. In particular, while foreign branches are more likely to require collateral and lend at shorter maturities than domestic banks, these differences become less pronounced as time since entry increases. In terms of economic significance, a one standard-deviation increase in time since entry (by 1.85 years) from the mean is associated with a 6 percentage points decrease in the relative likelihood of collateral and a 52 percent decrease in the maturity differential. Foreign subsidiaries instead begin to behave more like foreign banks, as time since becoming foreign owned increases. They begin to require more collateral and lend at shorter maturities as time passes. A one standard deviation increase in the time since becoming foreign owned (by 2.17 years) from the mean, is associated with a 13 percentage point increase in the relative likelihood of collateral and a 50 percent increase in the maturity differential by around 2 months. Interestingly, the directions and economic magnitudes of these effects are similar to those documented in Table 5 for the takeover of the former domestic bank from foreign investors. Consistent with the more frequent use of collateral and short maturities, the foreign bank loan rate discounts are found to increase over time. All in all, the results in Panel C suggest that differences between domestic and foreign banks with respect to collateral and maturity may relate to informational disadvantages arising from greater geographical and organizational

\footnotetext{
${ }^{46}$ We re-estimate equation (1) allowing for interactions with time since entry or time since becoming foreign owned, defined as the natural logarithm of the number of years between the date of loan origination and the date the bank entered Bolivia or became foreign owned. We estimate this specification using the larger sample in Panel B, as we do not have sufficient variation for the restricted sample of 689 loans of Panel A.
} 
distances. These findings are also not consistent with the "bank-fixed hypothesis", discussed in section 4.2, as the latter would imply time-invariant differences between domestic and foreign banks.

In the final part of Table 10 we also explore available variation in geographical and organizational distances. We re-estimate the specifications in Panel B allowing for interactions with Non-Local, a dummy variable that indicates whether the bank's headquarters are in a different location (region or country) than where the loan is originated. ${ }^{47}$ This variable intends to capture greater geographical and organizational distances between loan origination and the bank's headquarters. The omitted group in these specifications is local domestic banks as Non-Local is also included in the regressions. ${ }^{48}$ Foreign Branches is not interacted with Non-Local as in all cases foreign branches have their headquarters outside Bolivia. Domestic banks and foreign subsidiaries can be either local or non-local depending on whether the loan was originated in the region whether the bank is headquartered. The results in Panel D confirm our previous findings in Panels A and B relative to local domestic banks and additionally indicate that differences in maturities between local domestic banks and foreign subsidiaries become more pronounced as geographical distance increases. As before, collateral seems to play a more important role for foreign branches (i.e., a non-local foreign branch is 44.4 percentage points more likely to have collateral relative to a domestic local bank; a non-local foreign subsidiary is only 11.4 percent points more likely). Interestingly, geographical distance seems to make no difference in the relative use of collateral and maturity for domestic banks. Overall, the findings reported in this section are consistent with our third hypothesis that the use of contract terms such as collateral and maturity to overcome information frictions is associated with greater geographical and organizational distances.

\subsection{Bank ownership and ex post loan performance}

\footnotetext{
${ }^{47}$ While we know the precise location of a bank's headquarters we do not know the precise location of the branch that originates each loan or the precise location of each firm. We can only observe the region in which each loan is originated. The data availability does not allow us to study differences due to special price discrimination emanating from transportation costs and market power as in Agarwal and Hauswald (2010) and Degryse and Ongena (2005).

${ }^{48}$ Foreign Branch is not interacted with Non-Local as all loans originated by foreign branches are non-local as foreign branches have the headquarters are outside Bolivia. Domestic banks and foreign subsidiaries can be either local or non-local depending on whether the loan was originated in the region whether the bank is headquartered.
} 
In this final section, we compare the ex post performance of domestic and foreign bank loans. If foreign and domestic banks set loan conditions and price loans in an optimal way, we should not observe any systematic differences in the ex post performance of their loans, especially when holding differences in their clienteles fixed. We study two measures of ex post loan performance: arrears or defaults and net return on loans and present OLS regressions that compare the ex post performance of loans originated by domestic and foreign banks to the same firm in the same month for all loans in our sample, for secured and unsecured loans separately, for loans with maturities below and above the sample median, and for secured and unsecured loans each with shorter and longer maturities.

First, we define a dummy variable, Arrears or Default, that equals one if a loan is in arrears for more than 30 days or if it is downgraded to the default status (rating 5), and equals zero otherwise. Regressions in Panel A of Table 11 show that loans originated by foreign banks to the same firm in the same month are 3.5 percentage points more likely to go in arrears or default, consistent with foreign banks facing higher agency conflicts. This finding is driven by unsecured and longer maturity loans. ${ }^{49}$ In particular, we find no significant differences in repayment for secured and for short-term loans; significant differences are only found for unsecured and for long-term loans. When splitting the sample in two ways, the higher incidence of repayment problems for foreign bank loans is only confirmed for loans that are both unsecured and of longer maturity. The results thus suggest that foreign banks are able to effectively mitigate credit risk problems using collateral and shorter maturities. In unreported robustness checks, we also confirm these results with descriptive statistics or corresponding specifications with firm fixed effects (instead of firm $\times$ time fixed effects) to alleviate possible concerns that insignificant differences in some sub-samples are due to exhaustive fixed effects saturating variation.

(Insert Table 11 around here)

While foreign banks seem to experience higher arrears or defaults when they lend without collateral and at longer maturities, they still might be able to recover loans later on. Hence, we also compute the bank's net returns on each loan. Given the systematic differences in contract characteristics between domestic and foreign bank loans and differences in funding costs between domestic and foreign

\footnotetext{
${ }^{49}$ Note that results also hold when we include control variables as in previous regressions as well as the interest rate.
} 
banks, the bank's net return on loans provides a more comprehensive measure of loan performance. Following Haselmann, Schoenherr and Vig (2016) and Skrastins and Vig (2014) we define the gross return on a loan $(R O L)$ to firm $i$ from bank $j$ for the entire loan spell as:

$$
R O L_{i j}=\sum_{t=1}^{T} \frac{\text { LoanBalance }_{i j t}}{\sum_{t=1}^{T} \text { LoanBalance }_{i j t}}\left[\left(1-\mathbb{1}_{\{N P L=1\}}\right) r_{i j t}+\mathbb{1}_{\{N P L=1\}} \text { Loss }_{i j t}\right],
$$

where the first term stands for the ratio of the outstanding loan amount to firm $i$ from bank $j$ at the beginning of period $t$ (LoanBalance $i j t)$ to the sum of the outstanding loan amounts over the loan spell. The indicator function equals one when a loan has overdue payments between $t$ and $t+1, r_{i j t}$ is the interest rate on the loan, and $\operatorname{Loss}_{i j t}$ is the loss of the bank. We calculate the loss of the bank as the written-off amount or the overdue amount over the contract amount. The weights ensure that returns or defaults at the beginning of the loan spell receive more weight than those at the end of the loan spell when most of the loan has been repaid. To account for funding costs differences between domestic and foreign banks, we further subtract from the $R O L$ each bank's cost of deposits at loan origination. We refer to this as the Net Return on Loans and use it as our main measure of returns on loans in Panel B.

The results in Panel B show that on average foreign banks have 1.26 percentage points lower net returns on their loans than domestic banks. ${ }^{50}$ This is a more pronounced for unsecured loans (1.73 percentage points) as opposed to secured loans (insignificant) and for longer maturity (1.69 percentage points) than shorter maturity loans (0.82 percentage points). When splitting the sample, we find no significant difference in their net returns on loans that are both secured and of short maturity and the highest difference for loans that are both unsecured and of longer maturity (2.06 percentage points). In unreported robustness checks, we also confirm the results in Panel B using alternatively the gross return on loan $(R O L)$ or a gross return on loans using discounted weights as in Haselmann, et al. (2013). ${ }^{51}$

In summary, we find that foreign banks have a higher incidence of arrears or defaults and lower returns on their loans than domestic banks, consistent with foreign banks being at an informational disadvantage relative to domestic banks, even when lending to the same firm at the same time. While

\footnotetext{
${ }^{50}$ Notice that the number of observations reduces form 5,137 to 5,102 due to missing values for bank funding costs.

${ }^{51}$ Haselmann, et al. (2013) discount the weights in equation (3) to account for the time value of money.
} 
these findings are not consistent with our fourth hypothesis, we also find that collateral and maturity help foreign banks overcome these problems. ${ }^{52}$ The differences in loan performance are confirmed when we consider nonperforming loans (NPL) ratios from banks' balance sheets. Domestic and foreign-owned banks show economically and statistically significant differences in their NPL ratios. Specifically, foreign banks have an average NPL to total loans ratio of 17.8 percent as opposed to 11.3 percent for domestic banks, underlining the limitations that distance constraints impose on foreign banks in less developed financial markets such as Bolivia.

\subsection{Additional Robustness tests}

In this section we explore the potential role of selection biases, competition effects, and bank size on our results. To evaluate differences in the contract terms of domestic and foreign bank loans, our identification strategy uses within firm-time variation by comparing the contract terms of domestic and foreign banks when lending to the same firm in the same month. The advantage of our identification strategy is that it allows us to control for differences in the clientele of domestic and foreign banks and thus avoid cherry picking and home bias concerns. The disadvantage is that our estimates are only based on a sub-sample of firms: those with multiple bank-lending relationships that receive multiple loans within a given month. Clearly such firms are not a random draw of the population: they are the largest firms. This creates selection concerns. There could also be concerns about possible competition effects. Since these firms can more easily turn to one of their existing lenders for credit, they may be able to play one bank against each other for better terms. To study the potential role of such factors we perform several robustness tests.

First, we re-estimate equation (1) using either all loans in the sample ("universe"). This allows us to study whether our key findings in Tables 3 and 4 also hold for the larger population of loans and firms in Bolivia. Admittedly, identification in this case is less clean as the firm $\times$ time fixed effects are replaced with firm and time fixed effects. As can be observed in Table 12 (Panel A), results for the "universe" are

\footnotetext{
${ }^{52}$ This result is similar to findings in Agarwal and Hauswald (2010) that relying primarily on soft information only reduces arrear incidence in the case of low distance but not high distance between borrowers and banks. The findings are also consistent with DeYoung, Glennon and Nigro (2008) that while defaults on small business loans in rural United States increase in distance between borrower and banks, the use of hard-information tools such as credit scoring dampens this effect substantially.
} 
qualitatively and quantitatively similar to those reported in Tables 3 and 4 for our sub-sample. (Table 12 reports specifications corresponding to those reported in columns III and VIII of Table 3 and column III of Table 4.) Overall, these results confirm that our findings are relevant beyond our limited and selective sample of firms with access to both domestic and foreign banks at the same time.

(Insert Table 12 here)

The "universe" includes both multiple and single relationship firms and thus can help assuage concerns that our findings are picking up a peculiarity of multiple relationship firms. Nevertheless, as an additional robustness test, we re-estimate equation (1) using loans to firms with single bank lending relationships throughout the sample period. Relative to firms in "our sample", such firms may have more difficulties to access credit from other banks. They may thus not be able to benefit from competition across banks. As can be observed in Panel B, results with respect to collateral and maturity are similar to those presented in Tables 3 and 4 for "our sample". With respect to loan interest rates, we find significantly smaller interest rate discounts that are not statistically significant. This suggests that while firms with multiple bank lending relationships may be compensated with lower interest rates for worse other loan conditions, single relationship firms with fewer alternatives are not. This is consistent with the theoretical predictions in Sengupta (2007) and mirrors results in Agarwal and Hauswald (2010) and Ioannidou and Ongena (2010) on hold-up rents in bank-lending relationships when competition is low.

To further examine the potential role of competition effects in "our sample", in Panels C-E we examine whether there is any systematic pattern in the order in which firms obtain loans from domestic and foreign banks and whether results are sensitive to any such ordering. This could be informative as to whether firms use first one type of banks for their funding needs, and another for their remaining needs. For the 5,137 loans in our sample, we find that in 2,330 cases the domestic bank was first, in 2,417 cases the foreign bank was first, and in 390 cases the foreign and domestic banks granted the loans on exactly 
the same day. ${ }^{53}$ Re-estimating equation (1) for these three sub-samples yields results that are similar to those in Tables 3 and 4 and detects no statistically significant differences between them.

All in all, our results in Table 12 indicate that our key findings on collateral and maturity are not only relevant for our limited and selective sample of firms with access to both domestic and foreign banks at the same time, but hold for all firms. Access to multiple banks seems however to affect the loan conditionality that firms may be able to obtain: while firms with multiple banks are compensated with lower interest rates for the worse other loan conditions, single relationship firms are not.

In a final robustness test, we show that systematic differences in the average global or local size of domestic and foreign banks do not explain our key findings with respect to collateral and maturity. As shown in Table 1, most foreign banks are much larger in size than most domestic banks. Differences in global bank size may correlate with more hierarchical organizational structures, but also better access to capital markets. To investigate this possibility, we add global bank size measured as the natural logarithm of consolidated total assets as an additional control variable in equation (1). Results are presented in columns of Table 13. We find that in the collateral and interest rate regressions, global bank size produces similar results as foreign ownership, suggesting that global bank size maybe part of the reason foreign banks behave differently. Relative to earlier estimates, some of the differences between domestic and foreign banks are marginally absorbed by differences in bank size. Nevertheless, in all specifications, the coefficients of Foreign Bank retain their signs and statistical significance, suggesting that differences between domestic and foreign banks go beyond mere differences in size. ${ }^{54}$

(Insert Table 13 about here)

\footnotetext{
${ }^{53}$ Loans originated on the same day could also be part of informal syndicates and could explain some of the observed differences in the loan contract terms between domestic and foreign bank loans if domestic and foreign banks were more or less likely to engage in such informal syndicates.

${ }^{54}$ One concern with these results is that there is almost no overlap in the distribution of global bank size between foreign and domestic banks. Hence, in unreported regressions available on request, we re-estimate the specifications in Table 13 using a sub-sample of domestic and foreign banks in which the two groups are not significantly different in size. In particular, we exclude the four largest foreign banks (Citibank, ABN Amro, Banco do Brasil, and Banco de la Nacion Argentina) or the three largest banks (i.e., Citibank, ABN Amro, and Banco do Brasil) and the two smallest domestic banks (i.e., Banco Ganadero and Banco Economico). Results in both cases remain unchanged.
} 
In Panel B we perform a similar exercise using bank size measured at a local level (i.e., total assets in Bolivia). While some foreign banks are large international organizations, their operations in Bolivia constitute a miniscule part of their global operations, which may explain why they are disadvantaged relative to domestic banks. As can be observed in Panel B this does not explain our key findings with respect to collateral and maturity. While as before, bank size enters significantly in some though not all regressions, its inclusion in the specification does not affect the size or the statistical significance of the foreign bank coefficients. The coefficient of bank size indicates that loans from larger banks are less likely to have collateral and have shorter maturities. We find no differences in loan interest rates.

\section{Conclusions}

With the increase of the worldwide globalization of financial markets, the assessment of foreign bank entry and presence has become an important question for researchers and policymakers alike. The effects of foreign bank participation are not only important for the development of the banking sector in a country but will also have real effects on the economy as a whole, especially in countries with bank-finance dependent firms. Most country-level and cross-country studies confirm that foreign banks tend to lend to large and transparent firms and thus "cherry-pick" clients, leaving the difficult firms to domestic banks. Fewer studies find that foreign and large banks engage in lending to both smaller and larger firms.

Our findings suggest that foreign banks use contract design and other assessment mechanisms as a way to overcome their informational disadvantages vis-à-vis their local competitors, with both types of lenders co-existing in equilibrium. Holding differences in borrower clienteles constant, we find that foreign banks use collateral, maturity, and credit scoring models to overcome distance constraints emanating from their size and steeper organizational structures and show that such mechanisms are effective in terms of ex post loan performance. Such mechanisms however may carry important limitations. If domestic lenders cannot cover the remaining segments of the market, the foreign banks' stronger reliance on collateral and short maturity loans may reduce the options for firm investment. It may also have important repercussions from a capital allocation perspective as it may imply a shift towards firms with short-term financing needs and with pledgeable assets both on the intensive and extensive margin, limiting the potentially beneficial role foreign banks can play in developing countries. 


\section{References}

Agarwal, Sumit, and Robert Hauswald, 2010, Distance and private information in lending, Review of Financial Studies 23, 2757-2788.

Aghion, P., and J. Tirole, 1997, Formal and real authority in organizations, Journal of Political Economy 105, 1-29.

Aghion, Philippe, and Patrick Bolton, 1997, A theory of trickle-down growth and development, Review of Economic Studies 64, 151-172.

Anderson, T. W., and H. Rubin, 1949, Estimation of the parameters of a single equation in a complete system of stochastic equations, Annals of Mathematical Statistics 20, 46-63.

Barnea, Amir, Robert A. Haugen, and Lemma W. Senbet, 1980, A rationale for debt maturity structure and call provisions in the agency theoretic framework, Journal of Finance 35, 1223-1234.

Beck, Thorsten, Patrick Behr, and Andreas Madestam, 2014, Sex and credit: Is there a gender bias in lending?, European Banking Center Discussion Paper No. 2012-017.

Beck, Thorsten, Asli Demirgüç-Kunt, and María Soledad Martínez Pería, 2011, Bank financing for smes: Evidence across countries and bank ownership types, Journal of Financial Services Research 39, 35-54.

Beck, Thorsten, and María Soledad Martínez Pería, 2010, Foreign bank participation and outreach: Evidence from mexico, Journal of Financial Intermediation 19, 52-73.

Bellucci, Andrea, Alexander Borisov, Germana Giombini, and Alberto Zazzaro, 2015, Collateral and local lending: Testing the lender-based theory, Working Paper No. 401 (Centre for Studies in Economics and Finance, University of Naples).

Berg, Tobias, Anthony Saunders, and Sascha Steffen, 2016, The total costs of corporate borrowing in the loan market: Don't ignore the fees, Journal of Finance 71, 1357-1392.

Berger, Allen N., Scott W. Frame, and Vasso Ioannidou, 2011, Tests of ex ante versus ex post theories of collateral using private and public information, Journal of Financial Economics 100, 85-97.

Berger, Allen N., Leora F. Klapper, María Soledad Martínez Pería, and Rida Zaidi, 2008, Bank ownership type and banking relationships, Journal of Financial Intermediation 17, 37-62.

Berger, Allen N., Leora F. Klapper, and Gregory F. Udell, 2001, The ability of banks to lend to informationally opaque small businesses, Journal of Banking \& Finance 25, 2127-2167.

Berger, Allen N., Nathan H. Miller, Mitchell A. Petersen, Raghuram G. Rajan, and Jeremy C. Stein, 2005, Does function follow organizational form? Evidence from the lending practices of large and small banks, Journal of Financial Economics 76, 237-269.

Berger, Allen N., Richard J. Rosen, and Gregory F. Udell, 2007, Does market size structure affect competition? The case of small business lending, Journal of Banking \& Finance 31, 11-33.

Berger, Allen N., and Gregory F. Udell, 1995, Relationship lending and lines of credit in small firm finance, Journal of Business 68, 351-81.

Berger, Allen N., and Gregory F. Udell, 2006, A more complete conceptual framework for sme finance, Journal of Banking \& Finance 30, 2945-2966.

Berlin, Mitchell, and Loretta J. Mester, 1992, Debt covenants and renegotiation, Journal of Financial Intermediation 2, 95-133.

Besanko, David, and Anjan V. Thakor, 1987, Collateral and rationing: Sorting equilibria in monopolistic and competitive credit markets, International Economic Review, Department of Economics, University of Pennsylvania and Osaka University Institute of Social and Economic Research Association 28, 671-89.

Bester, Helmut, 1985, Screening vs. Rationing in credit markets with imperfect information, American Economic Review 75, 850-855.

Bester, Helmut, 1987, The role of collateral in credit markets with imperfect information, Europena Economic Journal 31, 887-899.

Bharath, Sreedhar T. , Sandeep Dahiya, Anthony Saunders, and Anand Srinivasan, 2011, Lending relationships and loan contract terms, Review of Financial Studies 24, 1141-1203.

Bolton, Patrick, and Mathias Dewatripont, 1994, The firm as a communication network, The Quarterly Journal of Economics 109, 809-839.

Boot, A. W. A., A. V. Thakor, and G. F. Udell, 1991, Secured lending and default risk - equilibriumanalysis, policy implications and empirical results, Economic Journal 101, 458-472. 
Boot, Arnoud W. A., and Anjan V. Thakor, 1994, Moral hazard and secured lending in an infinitely repeated credit market game, International Economic Review 35, 899-920.

Bruno, Valentina, and Robert Hauswald, 2014, The real effect of foreign banks, Review of Finance 18, $1683-1716$.

Cameron, A. Colin, and Pravin K. Trivedi, 2005. Microeconometrics: Methods and applications (Cambridge University Press, New York).

Cerqueiro, Geraldo, Hans Degryse, and Steven Ongena, 2011, Rules versus discretion in loan rate setting, Journal of Financial Intermediation 20, 503-529.

Cerutti, Eugenio, Giovanni Dell'Ariccia, and Maria Soledad Martínez Pería, 2007, How banks go abroad: Branches or subsidiaries?, Journal of Banking \& Finance 31, 1669-1692.

Claessens, Stijn, and Neeltje van Horen, 2014, Foreign banks: Trends and impact, Journal of Money Credit and Banking 46, 295-326.

Clarke, George R. G., Robert Cull, María Soledad Martínez Pería, and Susana M. Sanchez, 2005, Bank lending to small businesses in latin america: Does bank origin matter?, Journal of Money, Credit and Banking 37, 83-118.

Crawford, V., and J. Sobel 1982, Strategic information transmission, Econometrica 50, 1431--1451.

De Haas, Ralph, Daniel Ferreira, and Anita Taci, 2010, What determines the composition of banks' loan portfolios? Evidence from transition countries, Journal of Banking \& Finance 34, 388-398.

De la Torre, Augusto, María Soledad Martínez Pería, and Sergio L. Schmukler, 2010, Bank involvement with smes: Beyond relationship lending, Journal of Money, Credit and Banking 34, 2280-2293.

Degryse, Hans, Vasso Ioannidou, and Erik von Schedvin, 2016, On the non-exclusivity of loan contracts: An empirical investigation, Management Science, forthcoming.

Degryse, Hans, Luc Laeven, and Steven Ongena, 2009, The impact of organizational structure and lending technology on banking competition, Review of Finance 13, 225-259.

Degryse, Hans, and Steven Ongena, 2005, Distance, lending relationships, and competition, Journal of Finance 60, 231-266.

Dell'Ariccia, Giovanni, and Robert Marquez, 2004, Information and bank credit allocation, Journal of Financial Economics 72, 185-214.

Detragiache, Enrica, Poonam Gupta, and Thierry Tressel, 2008, Foreign banks in poor countries: Theory and evidence, Journal of Finance 63, 2123-2160.

DeYoung, Robert, Dennis Glennon, and Peter Nigro, 2008, Borrower-lender distance, credit scoring, and loan performance: Evidence from informational-opaque small business borrowers, Journal of Financial Intermediation 17, 113-143.

Diamond, Douglas W., 1991, Debt maturity structure and liquidity risk, Quarterly Journal of Economics 106, 709-737.

Elsas, Ralf, and Jan Pieter Krahnen, 1998, Is relationship lending special? Evidence from credit-file data in germany, Journal of Banking \& Finance 22, 1283-1316.

Finlay, Keith, and Leandro M. Magnusson, 2009, Implementing weak-instrument robust tests for a general class of instrumental-variables models, The Stata Journal 9, 398-421.

Fisman, Raymond, Daniel Paravisini, and Vikrant Vig, 2016, Cultural proximity and loan outcomes American Economic Review, forthcoming.

Flannery, Mark J., 1986, Asymmetric information and risky debt maturity choice, Journal of Finance 41, 19-37.

Giannetti, Mariassunta, and Steven Ongena, 2009, Financial integration and firm performance: Evidence from foreign bank entry in emerging markets, Review of Finance 13, 181-223.

Giannetti, Mariassunta, and Steven Ongena, 2012, "Lending by example": Direct and indirect effects of foreign banks in emerging markets, Journal of International Economics 86, 167-180.

Giannetti, Mariassunta, and Yishay Yafeh, 2012, Do cultural differences between contracting parties matter? Evidence from syndicated bank loans, Management Science 58, 365-383.

Gormley, Todd A., 2010, The impact of foreign bank entry in emerging markets: Evidence from india, Journal of Financial Intermediation 19, 26-51.

Gormley, Todd A., 2014, Costly information, entry, and credit access, Journal of Economic Theory 154, 633-667.

Harhoff, Dietmar, and Timm Körting, 1998, Lending relationships in Germany - empirical evidence from survey data, Journal of Banking \& Finance 22, 1317-1353. 
Hart, Oliver, and John Moore, 1994, A theory of debt based on the inalienability of human capital, Quarterly Journal of Economics 109, 841-879.

Haselmann, Rainer, Katharina Pistor, and Vikrant Vig, 2010, How law affects lending, Review of Financial Studies 23, 549-580.

Haselmann, Rainer, David Schoenherr, and Vikrant Vig, 2016, Rent-seeking in elite networks, SAFE Working Paper Series (Research Center SAFE - Sustainable Architecture for Finance in Europe, Goethe University Frankfurt).

Hauswald, Robert, and Robert Marquez, 2006, Competition and strategic information acquisition in credit markets, Review of Financial Studies 19, 967--1000.

Holmstrom, Bengt, and Jean Tirole, 1997, Financial intermediation, loanable funds, and the real sector, Quarterly Journal of Economics 112, 663-691.

Ioannidou, Vasso, and Steven Ongena, 2010, "Time for a change": Loan conditions and bank behavior when firms switch banks, Journal of Finance 65, 1847-1877.

Keys, Benjamin J., Tanmoy Mukherjee, Amit Seru, and Vikrant Vig, 2010, Did securitization lead to lax screening? Evidence from subprime loans, Quarterly Journal of Economics 125, 307-362.

Kleibergen, F., and R. Paap, 2006, Generalized reduced rank tests using the singular- value decomposition, Journal of Econometrics 127, 97-126.

Liberti, Jose M, and Atif R Mian, 2009, Estimating the effect of hierarchies on information use, Review of Financial Studies 22, 4057-4090.

Liberti, Jose Maria, Amit Seru, and Vikrant Vig, 2016, Information, credit, and organization, Available at SSRN: http://ssrn.com/abstract $=2798608$

Machauer, Achim, and Martin Weber, 1998, Bank behavior based on internal credit ratings of borrowers, Journal of Banking \& Finance 22, 1355-1383.

Mian, Atif, 2006, Distance constraints: The limits of foreign lending in poor economies, Journal of Finance 61, 1465-1505.

Myers, Stewart C., 1977, Determinants of corporate borrowing, Journal of Financial Economics 5, 147175.

Ortiz-Molina, Hernan, and Maria F. Penas, 2008, Lending to small businesses: The role of loan maturity in addressing information problems, Small Business Economics 30, 361-383.

Petersen, Mitchell A., 2004, Information: Hard and soft, (Kellog School of Management, Northwestern University, and NBER).

Petersen, Mitchell A., and Raghuram G. Rajan, 1994, The benefits of lending relationships: Evidence from small business data, Journal of Finance 49, 3-37.

Qian, J., and P. E. Strahan, 2007, How laws and institutions shape financial contracts: The case of bank loans, Journal of Finance 62, 2803-2834.

Radner, Roy, 1993, The organization of decentralized information processing, Econometrica 61, 11091146.

Rajan, Raghuram G., 1992, Insiders and outsiders: The choice between informed and arm's-length debt, Journal of Finance 47, 1367-400.

Rajan, Uday, Amit Seru, and Vikrant Vig, 2015, The failure of models that predict failure: Distance, incentives, and defaults, Journal of Financial Economics 115, 237-260.

Roberts, Michael R., and Toni M. Whited, 2012, Endogeneity in empirical corporate finance, in Milton Harris and Rene M. Stulz George M. Constantinides, ed.: Handbook of the economics of finance (Elsevier).

Sah, Raaj Kumar, and Joseph E. Stiglitz, 1986, The architecture of economic systems: Hierarchies and polyarchies, American Economic Review 76, 716-727.

Sengupta, Rajdeep, 2007, Foreign entry and bank competition, Journal of Financial Economics 84, 502528.

Sirtaine, Sophie, Ilias Skamnelos, and Sissy Frank, 2004, Bolivia: Challenges in the corporate and banking sectors, Working Paper (World Bank, Washington DC).

Skrastins, Janis, and Vikrant Vig, 2014, How organzational hierarchy affects information production, Working Paper.

Stein, Jeremy C. , 2002, Information production and capital allocation: Decentralized versus hierarchical firms, Journal of Finance 57, 1891-1921. 
Stock, J. , and M. Yogo, eds., 2005. Testing for weak instruments in linear iv regression (Cambridge: Cambridge University Press).

von Thadden, Ernst-Ludwig, 2004, Asymmetric information, bank lending and implicit contracts: The winner's curse, Finance Research Letters 1, 11-23.

Wooldridge, J. M., 2002. Econometric analysis of cross section and panel data (Cambridge, MA: MIT Press). 


\section{Table 1: Summary Statistics for Commercial Banks Operating in Bolivia}

The table provides summary statistics for all commercial banks that were active in Bolivia between March 1999 and December 2003.We distinguish between foreign branches, foreign subsidiaries and domestic banks. A bank is considered to be foreign if more that $50 \%$ of its shares are foreign-owned. Entry/ Acquisition indicates at which point in time the bank entered the market or was acquired by a foreign bank. Consolidated Total Assets reports the average value of banks' total assets globally in millions of US\$ during the sample period. Total Assets in Bolivia reports the average value of bank's total assets in Bolivia in millions of US\$ during the sample period. Market Share stands for a bank's total loans in the country to the total loans in the country per month. Cost of Deposits stands for the average interest rate on dollar deposits in a month.

\begin{tabular}{|c|c|c|c|c|c|c|c|c|c|}
\hline \multirow[t]{2}{*}{$\overline{\text { Bank }}$} & \multirow{2}{*}{$\begin{array}{c}\text { Entry/ } \\
\text { Acquisition }\end{array}$} & \multicolumn{2}{|c|}{ Consolitated Total Assets } & \multicolumn{2}{|c|}{ Total Assets in Bolivia } & \multicolumn{2}{|c|}{ Market Share } & \multicolumn{2}{|c|}{ Cost of Deposits } \\
\hline & & Mean & Std Dev & Mean & Std Dev & Mean & Std Dev & Mean & Std Dev \\
\hline \multicolumn{10}{|l|}{ Foreign Branches } \\
\hline Citibank* & $01 / 01 / 66$ & 975134.000 & 198429.000 & 262.180 & 39.732 & 0.069 & 0.024 & 3.034 & 1.634 \\
\hline ABN Amro* & 07/08/98 & 530089.000 & 48568.000 & 22.342 & 2.741 & 0.014 & 0.007 & 4.721 & 0.454 \\
\hline Banco do Brasil* & 07/01/61 & 76124.000 & 16741.000 & 32.615 & 9.776 & 0.018 & 0.012 & 3.938 & 1.324 \\
\hline $\begin{array}{l}\text { Banco de la Nación Argentina* } \\
\text { Foreign Subsidiaries }\end{array}$ & $04 / 28 / 58$ & 14614.171 & 4031.653 & 28.024 & 6.983 & 0.016 & 0.012 & 5.320 & 1.361 \\
\hline Banco Santa Cruz & 07/17/98 & 833.479 & 354.155 & 830.479 & 303.146 & 0.105 & 0.044 & 3.003 & 1.686 \\
\hline Banco de Crédito de Bolivia & $12 / 30 / 92$ & 589.057 & 97.402 & 590.053 & 96.841 & 0.161 & 0.053 & 4.245 & 1.438 \\
\hline Banco Solidario & 03/15/99 & 94.936 & 6.970 & 94.936 & 6.970 & 0.004 & 0.002 & 5.509 & 1.850 \\
\hline \multicolumn{10}{|l|}{ Domestic } \\
\hline Banco Industrial & & 682.490 & 48.450 & 682.490 & 48.450 & 0.263 & 0.054 & 4.021 & 1.366 \\
\hline Banco Nacional de Bolivia & & 621.065 & 17.808 & 621.065 & 17.808 & 0.118 & 0.047 & 5.037 & 1.434 \\
\hline Banco Mercantil & & 598.895 & 31.616 & 598.895 & 31.616 & 0.108 & 0.038 & 4.691 & 1.514 \\
\hline Banco de la Unión & & 443.784 & 90.026 & 443.784 & 90.026 & 0.060 & 0.027 & 5.886 & 1.766 \\
\hline Banco Económico & & 284.716 & 36.613 & 284.716 & 36.613 & 0.039 & 0.020 & 6.265 & 1.503 \\
\hline Banco Ganadero & & 207.390 & 21.950 & 207.390 & 21.950 & 0.046 & 0.016 & 5.586 & 1.599 \\
\hline
\end{tabular}




\section{Table 2: Summary Statistics}

The table reports summary statistics for the entire sample of 32,279 loans to 2,672 unique firms, referred to as "Universe", during the sample period. Summary statistics are also provided separately for loans originated by foreign and domestic banks. All variables are defined in Table A1 in the Appendix. The stars next to the mean values of domestic bank loans under "Universe" indicate whether the differences between domestic and foreign banks are statistically significant using the $t$-test. The second part of the table "Our Sample", reports summary statistics for a sub-sample of 5,137 loans to 287 firms that borrow from both domestic and foreign banks in the same month and compares it to the "Universe". Statistics are provided for all loans in "Our Sample" as well as for foreign and domestic banks separately. The stars next to each mean value indicate whether it is statistically different from its corresponding value for the "Universe" using a sample adjusted $t$-test. ***, ${ }^{* *}$, and * indicate significance at the $1 \%, 5 \%$, and $10 \%$ levels, respectively.

\begin{tabular}{|c|c|c|c|c|c|c|c|c|c|c|c|c|c|c|}
\hline \multirow{3}{*}{ Variable Names } & \multicolumn{6}{|c|}{ Universe } & \multicolumn{8}{|c|}{ Sample } \\
\hline & \multicolumn{2}{|c|}{ All } & \multicolumn{2}{|c|}{ Foreign } & \multicolumn{2}{|c|}{ Domestic } & \multicolumn{3}{|c|}{ All } & \multicolumn{2}{|c|}{ Foreign } & \multicolumn{3}{|c|}{ Domestic } \\
\hline & Mean & St. Dev. & Mean & St. Dev. & Mean & St. Dev. & & Mean & St. Dev. & Mean & St. Dev. & Mean & & St. Dev. \\
\hline \multicolumn{15}{|l|}{ Loan Terms } \\
\hline Installment & 0.470 & 0.499 & 0.500 & 0.500 & $0.450 * * *$ & 0.498 & 0.461 & & 0.499 & 0.482 & 0.500 & 0.437 & & 0.496 \\
\hline Amount & 161,908 & 468,898 & 204,725 & 564,162 & $134,714 * * *$ & 394,297 & 251,098 & $* * *$ & 524,793 & $239,967 * * *$ & 436,543 & 263,231 & 1 *** & 606,387 \\
\hline Collateral & 0.245 & 0.430 & 0.376 & 0.484 & $0.161 * * *$ & 0.368 & 0.331 & $* * *$ & 0.470 & $0.461 * * *$ & 0.499 & 0.188 & $3 * * *$ & 0.391 \\
\hline Maturity & 10.859 & 16.272 & 8.304 & 10.926 & $12.481 * * *$ & 18.717 & 8.817 & $* * *$ & 11.211 & $7.049 * * *$ & 7.382 & 10.744 & $* * *$ & 14.007 \\
\hline Interest Rate & 13.448 & 2.887 & 13.041 & 3.020 & $13.706 * * *$ & 2.769 & 12.617 & $* * *$ & 2.951 & $12.203 * * *$ & 2.863 & 13.069 & $* *$ & 2.979 \\
\hline Loan Spread & 9.949 & 2.763 & 9.352 & 2.990 & $10.328 * * *$ & 2.537 & 9.155 & $* * *$ & 2.594 & $8.774 * * *$ & 2.654 & 9.570 & & 2.460 \\
\hline \multicolumn{15}{|l|}{ Legal Structure } \\
\hline Sole Proprietorship & 0.125 & 0.331 & 0.096 & 0.295 & $0.144 * * *$ & 0.351 & 0.046 & $* * *$ & 0.210 & $0.034 * * *$ & 0.180 & 0.060 & $* * *$ & 0.237 \\
\hline General Partnership & 0.009 & 0.096 & 0.005 & 0.073 & $0.012 * * *$ & 0.108 & 0.005 & $* * *$ & 0.070 & $0.001 * * *$ & 0.039 & 0.009 & $*$ & 0.092 \\
\hline Limited Partnership & 0.130 & 0.337 & 0.139 & 0.346 & $0.125 * * *$ & 0.331 & 0.147 & $* * *$ & 0.354 & $0.166 * * *$ & 0.373 & 0.125 & & 0.331 \\
\hline Joint Stock Company & 0.229 & 0.420 & 0.273 & 0.446 & $0.201 * * *$ & 0.401 & 0.358 & $* * *$ & 0.479 & $0.381 * * *$ & 0.486 & 0.332 & $2 * * *$ & 0.471 \\
\hline Limited Liability Company & 0.486 & 0.500 & 0.472 & 0.499 & $0.494 * * *$ & 0.500 & 0.428 & $* * *$ & 0.495 & $0.411 * * *$ & 0.492 & 0.446 & $5 * * *$ & 0.497 \\
\hline Other & 0.020 & 0.142 & 0.014 & 0.118 & $0.025 * * *$ & 0.155 & 0.017 & $* *$ & 0.128 & $0.006 * * *$ & 0.077 & 0.028 & & 0.166 \\
\hline \multicolumn{15}{|l|}{ Bank Debt } \\
\hline Outstanding Debt & $1,991,796$ & $3,879,224$ & $2,410,193$ & $4,194,117$ & $1,726,061 * * *$ & $3,640,433$ & $5,452,792$ & $* * *$ & $6,474,100$ & $5,146,245 * * *$ & $6,395,487$ & $5,786,901$ & $* * *$ & $6,543,670$ \\
\hline \multicolumn{15}{|l|}{ Credit Quality } \\
\hline Past Non-Performance & 0.209 & 0.407 & 0.246 & 0.431 & $0.186 * * *$ & 0.389 & 0.304 & $* * *$ & 0.460 & $0.284 * * *$ & 0.451 & 0.325 & $5 * * *$ & 0.468 \\
\hline Rating 1 & 0.873 & 0.332 & 0.860 & 0.347 & $0.882 * * *$ & 0.323 & 0.857 & & 0.350 & $0.815 * * *$ & 0.388 & 0.903 & & 0.296 \\
\hline Rating 2 & 0.098 & 0.298 & 0.096 & 0.295 & 0.100 & 0.299 & 0.119 & $* * *$ & 0.324 & $0.150 * * *$ & 0.357 & 0.085 & $5 * * *$ & 0.279 \\
\hline Rating 3 & 0.024 & 0.154 & 0.035 & 0.185 & $0.017 * * *$ & 0.130 & 0.023 & & 0.150 & 0.033 & 0.179 & 0.012 & $2 * *$ & 0.110 \\
\hline Rating 4 & 0.004 & 0.063 & 0.008 & 0.091 & $0.001 * * *$ & 0.036 & 0.001 & $* * *$ & 0.028 & $0.001 * * *$ & 0.039 & 0 & $* * *$ & 0 \\
\hline \multicolumn{15}{|l|}{ Relationship Characteristics } \\
\hline Multiple Relationships & 0.555 & 0.497 & 0.620 & 0.485 & $0.514 * * *$ & 0.500 & 1 & & 0 & 1 & 0 & 1 & & 0 \\
\hline Rel Duration & 22.079 & 16.065 & 20.840 & 15.272 & $22.866 * * *$ & 16.500 & 23.071 & $* * *$ & 16.354 & $23.407 * * *$ & 16.543 & 22.705 & & 16.142 \\
\hline Scope & 0.259 & 0.438 & 0.224 & 0.417 & $0.281 * * *$ & 0.450 & 0.255 & & 0.436 & $0.206 * *$ & 0.404 & 0.310 & $* * *$ & 0.462 \\
\hline Primary & 0.714 & 0.452 & 0.665 & 0.472 & \multirow{2}{*}{\multicolumn{2}{|c|}{$\begin{array}{r}0.144 \\
19,741 \\
\end{array}$}} & 0.283 & $* * *$ & 0.451 & $0.312 * * *$ & 0.464 & 0.252 & $2 * * *$ & 0.434 \\
\hline Observations & \multicolumn{2}{|c|}{32,279} & \multicolumn{2}{|c|}{12,538} & & & \multicolumn{3}{|c|}{5,137} & \multicolumn{2}{|l|}{2,679} & \multicolumn{3}{|c|}{2,458} \\
\hline
\end{tabular}


Table 3: Determinants of Collateral and Maturity

The table reports OLS regressions for a sample of 5,137 loans to 287 firms that received a new loan from at least one foreign and one domestic bank in the same month during the period March 1999 to December 2003. The dependent variables are Collateral, a dummy variable indicating whether the loan contract includes the pledge of collateral and Maturity, the natural logarithm of one plus the number of months between loan origination and maturity. Columns I-V (VI-X) report regression results for Collateral (Maturity) as the dependent variable, with different control variables and for smaller and larger firms separately. Columns IV-V and IX-X report regression results for collateral and maturity for subsamples of firms with outstanding bank debt below or above the sample median, denoted as Smaller Firms and Larger Firms, respectively. Definitions of all variables can be found in Table A1 in the Appendix. Standard errors (presented in parentheses) are clustered at firm level. ***, **, and * indicate significance at the $1 \%, 5 \%$, and $10 \%$, respectively.

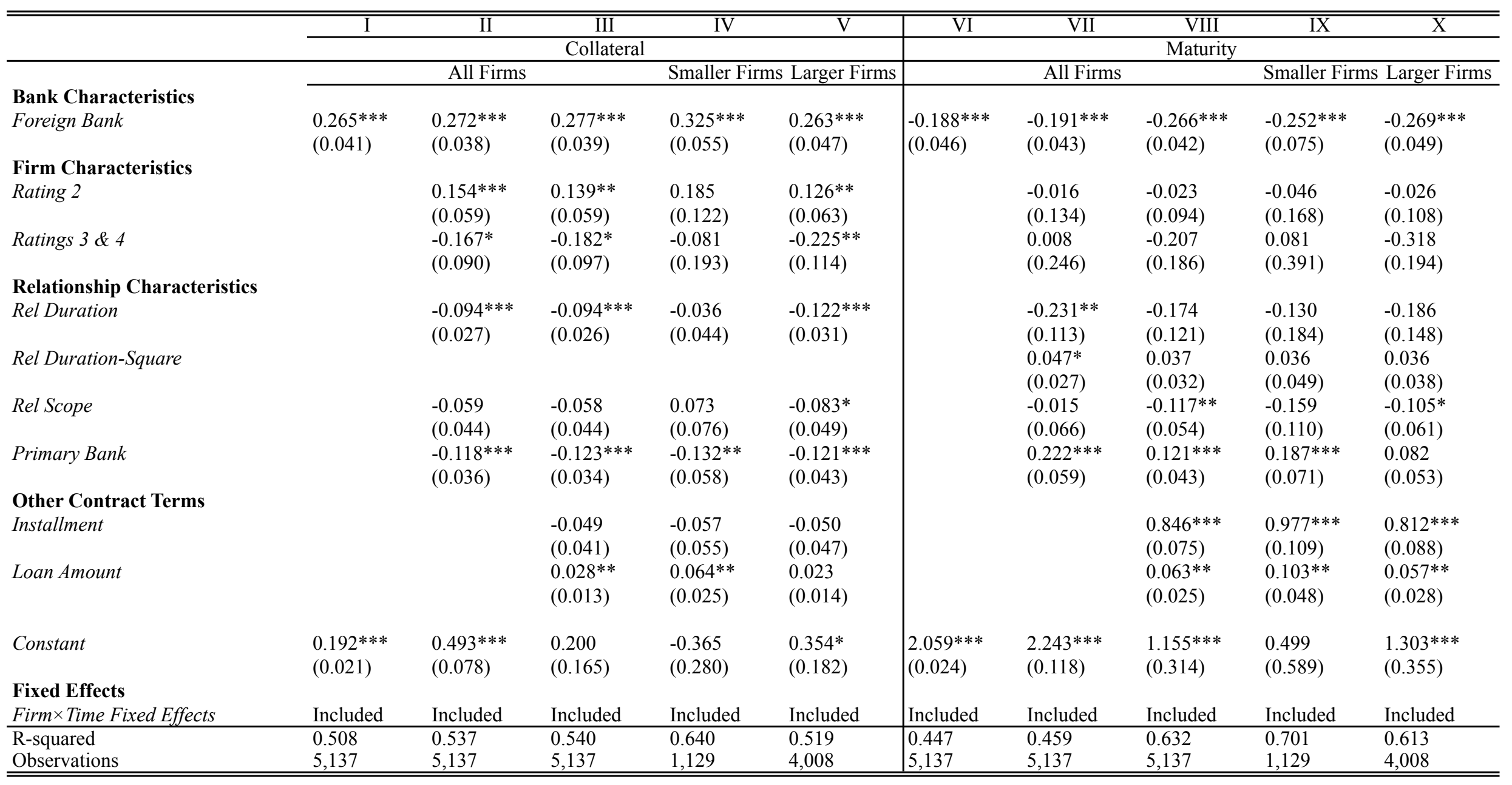


Table 4: Determinants of Loan Interest Rate

The table reports OLS regressions for a sample of 5,137 loans to 287 firms that received a new loan from at least one foreign and one domestic bank in the same month during the period March 1999 to December 2003. The dependent variable is Loan Spread, the loan interest rate minus the rate on US Treasury securities of comparable maturity at loan origination. Columns I-III report regression results with different control variables. Columns IV-V report regression results with all control variables, where the sample is divided between firms with outstanding bank debt below or above the sample median, denoted as Smaller Firms and Larger Firms, respectively. Columns VI-X report augmented specifications of those presented in Columns I-V where bank funding costs and market shares are added among the control variables. The definitions of all variables can be found in Table A1 in the Appendix. Standard errors (presented in parentheses) are clustered at firm level. ***,**, and * indicate significance at the $1 \%, 5 \%$, and $10 \%$, respectively.

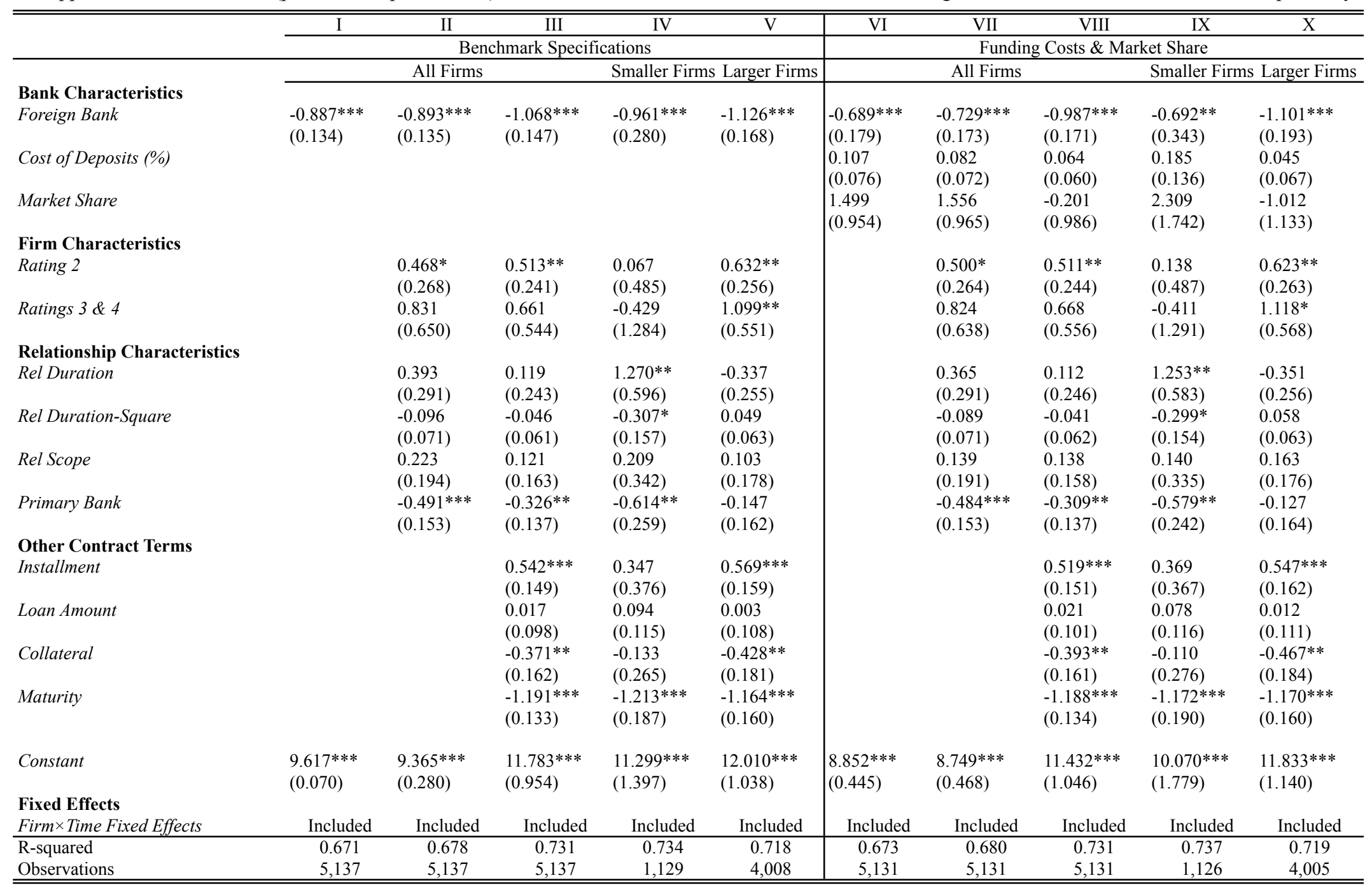


Table 5: Changes in Contract Terms after a Foreign Bank Takeover

The table reports the changes in the contract terms of a domestic bank, Banco Boliviano Americano (BBA), after it has been taken over by a foreign bank, Banco Credito de Bolivia (BCR), in May 1999 using a difference-in-difference analysis. To determine how contract terms change once the bank is taken over, we use a constant sample of firms that borrow from the acquired bank both before and after the takeover as well as other non-taken-over banks. In particular, we identify all loans from BBA in the year prior to the merger. We then trace any loans that these firms received from BCR in the three years following the acquisition, dropping all loans to firms that were already customers of BCR prior to the acquisition. We refer to these as the treated group. To control for changes in the macroeconomic conditions and the banking system over the comparison period, we use loans to the same firms by their other (non-taken-over) banks before and after the acquisition. We refer to these as the control group. Collateral is a dummy variable indicating whether the loan contract includes the pledge of collateral. Maturity is the natural logarithm of one plus the number of months between loan origination and maturity and Loan Spread is the loan interest rate minus the rate on US Treasury securities of comparable maturity at loan origination. Treated $i_{i k t}$ is a dummy variable that equals one for all loans in the treated group, and equals zero for all loans in the control group. After ${ }_{t}$ equals one for loans originated after May 1999, and equals zero for loans originated prior. All other variables are defined in Table A1 in the Appendix. Standard errors are reported in parentheses are clustered at the firm and bank level. $* * *, * *$, and $*$ indicate significance at the $1 \%, 5 \%$, and $10 \%$, respectively.

\begin{tabular}{|c|c|c|c|c|c|c|}
\hline & $\overline{\mathrm{I}}$ & II & III & IV & $\mathrm{V}$ & VI \\
\hline & Collateral & Maturity & Loan Spread & Collateral & Maturity & Loan Spread \\
\hline \multirow[t]{2}{*}{ Treated } & -0.116 & 0.008 & \begin{tabular}{l|l}
$0.716^{* * *}$ \\
\end{tabular} & -0.120 & -0.045 & $0.681 * * *$ \\
\hline & $(0.078)$ & $(0.088)$ & $(0.172)$ & $(0.073)$ & $(0.096)$ & $(0.169)$ \\
\hline \multirow[t]{2}{*}{ Treated $\times$ After } & $0.275^{* *}$ & $-0.476 * * *$ & -0.181 & $0.256^{* *}$ & $-0.377 * * *$ & -0.097 \\
\hline & $(0.118)$ & $(0.071)$ & $(0.259)$ & $(0.128)$ & $(0.090)$ & $(0.264)$ \\
\hline After & $\begin{array}{l}-0.005 \\
(0.057)\end{array}$ & $\begin{array}{l}-0.190^{* *} \\
(0.081)\end{array}$ & $\begin{array}{l}0.848 * * * \\
(0.262)\end{array}$ & & & \\
\hline \multicolumn{7}{|l|}{ Firm Characteristics } \\
\hline Rating 2 & $\begin{array}{l}0.053 \\
(0.041)\end{array}$ & $\begin{array}{l}-0.055 \\
(0.125)\end{array}$ & $\begin{array}{l}-0.408 \\
(0.345)\end{array}$ & $\begin{array}{l}0.054 \\
(0.042)\end{array}$ & $\begin{array}{l}-0.069 \\
(0.123)\end{array}$ & $\begin{array}{l}-0.366 \\
(0.328)\end{array}$ \\
\hline Ratings $3 \& 4$ & $\begin{array}{l}0.186^{*} \\
(0.112)\end{array}$ & $\begin{array}{l}0.073 \\
(0.232)\end{array}$ & $\begin{array}{l}-0.136 \\
(0.281)\end{array}$ & $\begin{array}{l}0.155 \\
(0.119)\end{array}$ & $\begin{array}{l}0.073 \\
(0.216)\end{array}$ & $\begin{array}{l}-0.078 \\
(0.225)\end{array}$ \\
\hline \multicolumn{7}{|c|}{ Relationship Characteristics } \\
\hline Rel Duration & $\begin{array}{l}0.010 \\
(0.015)\end{array}$ & $\begin{array}{l}-0.387 * * * \\
(0.082)\end{array}$ & $\begin{array}{l}0.342 * * * \\
(0.039)\end{array}$ & $\begin{array}{l}-0.011 \\
(0.023)\end{array}$ & $\begin{array}{l}-0.438^{* * *} \\
(0.093)\end{array}$ & $\begin{array}{l}0.285 * * * \\
(0.055)\end{array}$ \\
\hline Rel Duration-Square & & $\begin{array}{l}0.118^{* * *} \\
(0.029)\end{array}$ & $\begin{array}{l}-0.074 \\
(0.050)\end{array}$ & & $\begin{array}{l}0.154 * * * \\
(0.028)\end{array}$ & $\begin{array}{l}-0.060 \\
(0.043)\end{array}$ \\
\hline Rel Scope & $\begin{array}{l}-0.029 \\
(0.033)\end{array}$ & $\begin{array}{l}0.074 * \\
(0.044)\end{array}$ & $\begin{array}{l}-0.134 \\
(0.202)\end{array}$ & $\begin{array}{l}-0.004 \\
(0.034)\end{array}$ & $\begin{array}{l}0.037 \\
(0.047)\end{array}$ & $\begin{array}{l}-0.165 \\
(0.213)\end{array}$ \\
\hline Primary Bank & $\begin{array}{l}-0.077 \\
(0.076)\end{array}$ & $\begin{array}{l}-0.085 \\
(0.097)\end{array}$ & $\begin{array}{l}0.057 \\
(0.133)\end{array}$ & $\begin{array}{l}-0.079 \\
(0.074)\end{array}$ & $\begin{array}{l}-0.085 \\
(0.099)\end{array}$ & $\begin{array}{l}0.043 \\
(0.141)\end{array}$ \\
\hline \multicolumn{7}{|l|}{ Bank Characteristics } \\
\hline Global Bank Size & $\begin{array}{l}-0.223^{* * *} \\
(0.035)\end{array}$ & $\begin{array}{l}0.081 \\
(0.074)\end{array}$ & $\begin{array}{l}0.334 * * \\
(0.131)\end{array}$ & $\begin{array}{l}-0.217 * * * \\
(0.036)\end{array}$ & $\begin{array}{l}0.074 \\
(0.066)\end{array}$ & $\begin{array}{l}0.358 * * \\
(0.143)\end{array}$ \\
\hline Market Share & $\begin{array}{l}0.301 \\
(0.243)\end{array}$ & $\begin{array}{l}0.205 \\
(0.208)\end{array}$ & $\begin{array}{l}0.397 \\
(0.402)\end{array}$ & $\begin{array}{l}0.287 \\
(0.204)\end{array}$ & $\begin{array}{l}0.176 \\
(0.158)\end{array}$ & $\begin{array}{l}0.234 \\
(0.482)\end{array}$ \\
\hline Cost of Deposits & $\begin{array}{l}-0.008 \\
(0.015)\end{array}$ & $\begin{array}{l}0.077 * * \\
(0.030)\end{array}$ & $\begin{array}{l}0.319 * * * \\
(0.066)\end{array}$ & $\begin{array}{l}-0.008 \\
(0.015)\end{array}$ & $\begin{array}{l}0.066^{* *} \\
(0.029)\end{array}$ & $\begin{array}{l}0.310 * * * \\
(0.058)\end{array}$ \\
\hline Constant & $\begin{array}{l}1.576^{* * * *} \\
(0.188)\end{array}$ & $\begin{array}{l}1.945^{* * *} \\
(0.535)\end{array}$ & $\begin{array}{l}11.116^{* * *} \\
(1.038)\end{array}$ & $\begin{array}{l}1.510 * * * \\
(0.193)\end{array}$ & $\begin{array}{l}2.133 * * * \\
(0.495)\end{array}$ & $\begin{array}{l}11.092^{* * * *} \\
(1.043)\end{array}$ \\
\hline $\begin{array}{l}\text { Fixed Effects } \\
\text { Firm Fixed Effects } \\
\text { Year Fixed Effects }\end{array}$ & Included & Included & Included & $\begin{array}{l}\text { Included } \\
\text { Included }\end{array}$ & $\begin{array}{l}\text { Included } \\
\text { Included }\end{array}$ & $\begin{array}{l}\text { Included } \\
\text { Included }\end{array}$ \\
\hline R-squared & 0.293 & 0.238 & 0.683 & 0.304 & 0.251 & 0.689 \\
\hline Observations & 1,103 & 1,103 & 1,103 & 1,103 & 1,103 & 1,103 \\
\hline
\end{tabular}




\section{Table 6: Matching of Contract Terms}

The table reports results from a matching exercise using our sample of 5,137 loans to 287 firms that received a new loan from at least one foreign and one domestic bank in the same month during the period March 1999 to December 2003. For each specification, we estimate the average differences between the contract terms of domestic and foreign bank loans using the sub-sample of loans that satisfy the matching criteria in each case. In Column I, we match on firm identity and the month of loan origination. In Column II, we additionally match on ratings and relationship characteristics. In Column III, we also match on other contract terms as in Tables 3 and 4. For each matched sample, we report results for collateral, maturity, and loan spread. For the collateral regression, the dependent variable equals the difference in Collateral between the matched foreign and domestic bank loans. The dependent variables for the maturity and loan spread regressions are calculated similarly using Maturity and Loan Spread (see Table A1 in the Appendix for detailed definitions of Collateral, Maturity, and Loan Spread as well all other matching variables). For each dependent variable and sample, we estimate an OLS regression with only a constant term, clustering standard errors at the firm level. For each specification, we report the estimated constant term, the standard error, and the number of observations. ***, **, and * indicate significance at the $1 \%$, $5 \%$, and $10 \%$, respectively.

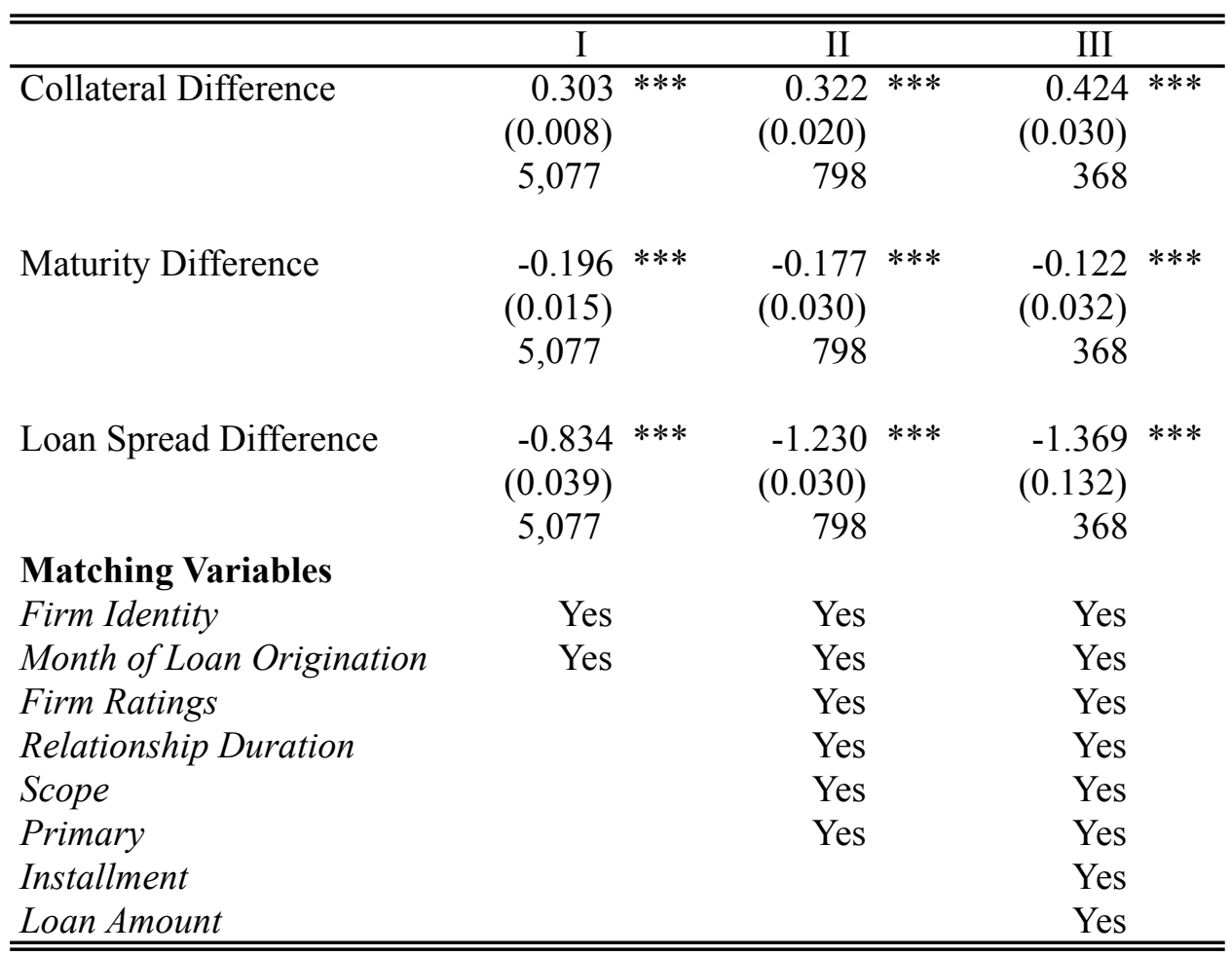




\section{Table 7: Joint Determination of Contract Terms}

The table reports estimation results for a sample of 5,137 loans to 287 firms that received a new loan from at least one foreign and one domestic bank in the same month during the period March 1999 to December 2003. Collateral is a dummy variable indicating whether the loan contract includes the pledge of collateral. Maturity is the natural logarithm of one plus the number of months between loan origination and maturity and Loan Spread is the loan interest rate minus the rate on US Treasury securities of comparable maturity at loan origination. Following Bharath, et al. (2011), we allow contract terms to be jointly determined in an IV framework. In particular, we use a dummy for industries with fewer tangible assets as an instrument for collateral, a dummy for regulated industries for maturity, and the average loan spread of all banks over the previous six months for loan spreads. Columns (a) report benchmark estimates similar to Tables 3 and 4, in columns (b) we add the instruments of the dependent variable, in column (c) we report estimates of the second-stage regression where the endogenous contract terms are instrumented by the respective instruments and in column (d) we use an indicator variable for sole proprietorship as an additional instrument for collateral as in Belluci, et al. (2015) and the term spread as an additional instrument for maturity as in Bharath, et al. (2010). Notice that we do not include firm $\times$ time fixed effects since the instruments do not vary in a given month within a firm. To assess whether the instruments are relevant, we report the CraggDonald test statistics and the relevant critical values based on Stock and Yogo (2005) as well as the Kleibergen-Paap rk LM statistics. To test the validity and relevance of the instruments, we report Hansen's J-statistic for overidentifying restrictions. All other variables are defined in Table A1 in the Appendix. Standard errors are reported in parentheses are clustered at the firm level. $* * *, *$, and $*$ indicate significance at the $1 \%, 5 \%$, and $10 \%$, respectively.

\begin{tabular}{|c|c|c|c|c|c|c|c|c|c|c|c|}
\hline & \multicolumn{3}{|c|}{ Collateral } & \multicolumn{4}{|c|}{ Maturity } & \multicolumn{4}{|c|}{ Spread } \\
\hline & $\begin{array}{c}\text { Probit } \\
\text { I (a) }\end{array}$ & $\begin{array}{c}\text { Probit } \\
\text { I (b) }\end{array}$ & $\begin{array}{l}\text { IV Probit } \\
\text { I (c) }\end{array}$ & $\begin{array}{l}\text { OLS } \\
\text { II (a) }\end{array}$ & $\begin{array}{l}\text { OLS } \\
\text { II (b) }\end{array}$ & $\begin{array}{l}\text { IV OLS } \\
\text { III (c) }\end{array}$ & $\begin{array}{l}\text { IV OLS } \\
\text { IV (d) }\end{array}$ & $\begin{array}{l}\text { OLS } \\
\text { II (a) }\end{array}$ & $\begin{array}{l}\text { IV OLS } \\
\text { II (b) }\end{array}$ & $\begin{array}{l}\text { IV OLS } \\
\text { III (c) }\end{array}$ & $\begin{array}{l}\text { IV OLS } \\
\text { IV (d) }\end{array}$ \\
\hline Foreign Bank & $\begin{array}{c}0.861 * * * \\
(0.113)\end{array}$ & $\begin{array}{c}0.864 * * * \\
(0.113)\end{array}$ & $\begin{array}{c}0.771 * * * \\
(0.207)\end{array}$ & $\begin{array}{c}-0.302 * * * \\
(0.034)\end{array}$ & $\begin{array}{c}-0.301 * * * \\
(0.034)\end{array}$ & $\begin{array}{c}-0.400 * * \\
(0.157)\end{array}$ & $\begin{array}{c}-0.204^{* *} \\
(0.087)\end{array}$ & $\begin{array}{c}-1.199 * * * \\
(0.153)\end{array}$ & $\begin{array}{c}-1.158 * * * \\
(0.153)\end{array}$ & $\begin{array}{c}-0.225 \\
(0.580)\end{array}$ & $\begin{array}{c}-0.574 \\
(0.378)\end{array}$ \\
\hline Maturity & $\begin{array}{l}0.164 * \\
(0.089)\end{array}$ & $\begin{array}{l}0.154 * \\
(0.088)\end{array}$ & $\begin{array}{c}1.611 * * * \\
(0.197)\end{array}$ & & & & & $\begin{array}{c}-1.284 * * * \\
(0.122)\end{array}$ & $\begin{array}{c}-1.270 * * * \\
(0.119)\end{array}$ & $\begin{array}{c}0.094 \\
(0.508)\end{array}$ & $\begin{array}{c}0.303 \\
(0.358)\end{array}$ \\
\hline Collateral & & & & $\begin{array}{c}0.108 * * \\
(0.052)\end{array}$ & $\begin{array}{l}0.102 * \\
(0.053)\end{array}$ & $\begin{array}{c}0.460 \\
(0.536)\end{array}$ & $\begin{array}{c}-0.253 \\
(0.295)\end{array}$ & $\begin{array}{l}-0.246 \\
(0.187)\end{array}$ & $\begin{array}{c}-0.321 * \\
(0.175)\end{array}$ & $\begin{array}{c}-2.412 \\
(2.264)\end{array}$ & $\begin{array}{c}-0.985 \\
(1.304)\end{array}$ \\
\hline Intangible Industry & & $\begin{array}{c}-0.513 * * \\
(0.222)\end{array}$ & $\begin{array}{c}-0.058 \\
(0.270)\end{array}$ & & & & & & & & \\
\hline Regulated Industry & & & & & $\begin{array}{c}-0.122 * \\
(0.074)\end{array}$ & $\begin{array}{c}-0.032 \\
(0.145)\end{array}$ & $\begin{array}{c}-0.207 * * \\
(0.097)\end{array}$ & & & & \\
\hline Term Spread & & & & & & & $\begin{array}{c}-0.010 \\
(0.024)\end{array}$ & & & & \\
\hline Past Regional Loan Spread & & & & & & & & & $\begin{array}{c}0.619 * * * \\
(0.120)\end{array}$ & $\begin{array}{c}0.770 * * * \\
(0.213)\end{array}$ & $\begin{array}{c}0.685 * * * \\
(0.166)\end{array}$ \\
\hline Other Controls & Included & Included & Included & Included & Included & Included & Included & Included & Included & Included & Included \\
\hline Weak Identification Statistics & & & & & & & & & & & \\
\hline $\begin{array}{l}\text { Cragg-Donald Wald F-statistic } \\
\text { Stock \& Yogo critical value }\end{array}$ & & & & & & $\begin{array}{c}31.398 \\
16.38\end{array}$ & $\begin{array}{c}38.644 \\
19.93\end{array}$ & & & $\begin{array}{c}40.469 \\
16.89\end{array}$ & $\begin{array}{l}43.52 \\
16.87\end{array}$ \\
\hline Underidentification Test & & & & & & & & & & & \\
\hline $\begin{array}{l}\text { Kleibergen-Paap rk LM statistic } \\
\text { p-value }\end{array}$ & & & & & & $\begin{array}{c}4.657 \\
(0.031)\end{array}$ & $\begin{array}{c}7.351 \\
(0.025)\end{array}$ & & & $\begin{array}{c}5.221 \\
(0.022)\end{array}$ & $\begin{array}{l}17.252 \\
(0.001)\end{array}$ \\
\hline Instrument Exogeneity Tests & & & & & & & & & & & \\
\hline $\begin{array}{l}\text { Hansen's J statistic } \\
\text { p-value }\end{array}$ & & & & & & & $\begin{array}{c}2.301 \\
(0.129)\end{array}$ & & & & $\begin{array}{c}1.139 \\
(0.566)\end{array}$ \\
\hline
\end{tabular}


Table 8: Bank Ownership and Loan Pricing

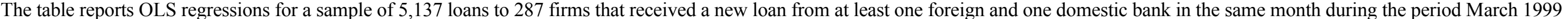

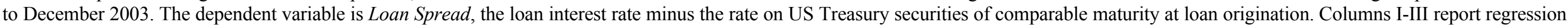

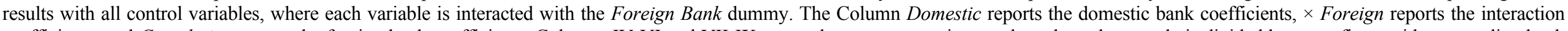

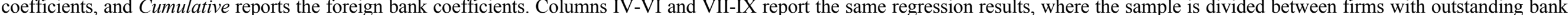

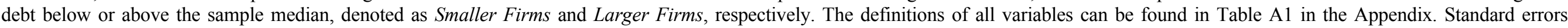
(presented in parentheses) are clustered at firm level. ***,**, and * indicate significance at the $1 \%, 5 \%$, and $10 \%$, respectively.

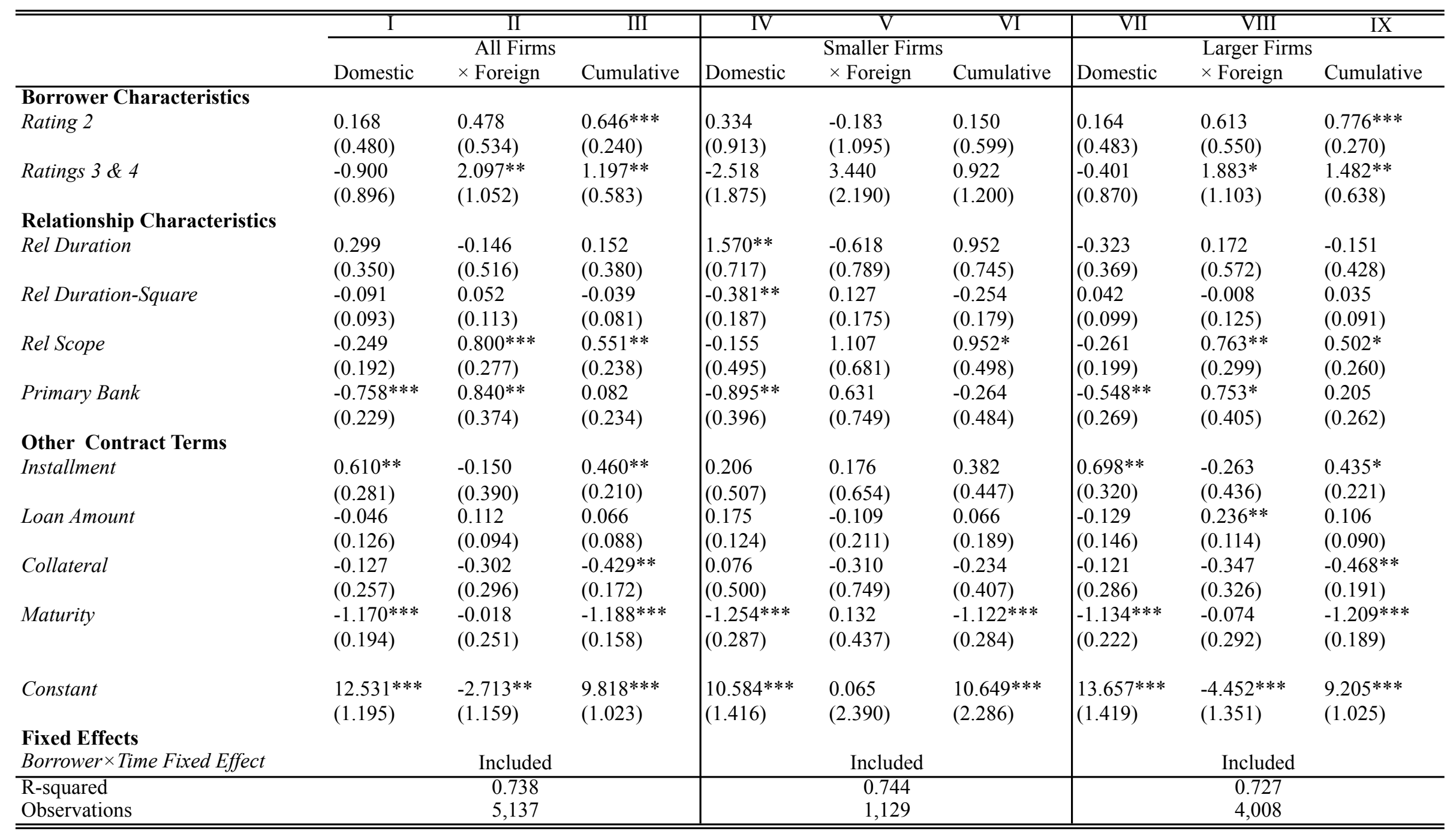




\section{Table 9: Hard Information Determinants of Loan Interest Rates}

The table reports OLS regressions for a sample of 5,137 loans to 287 firms that received a new loan from at least one foreign and one domestic bank in the same month during the period March 1999 to December 2003. In all specifications, the dependent variable is the Loan Spread, the loan interest rate minus the rate on US Treasury securities of comparable maturity at loan origination that is regressed on credit ratings and past performance measures. Columns I-II report regression results for foreign and domestic banks separately, while Columns III-VI additionally split these two specifications between firms with outstanding bank debt below or above the sample median for foreign and domestic banks, denoted as Smaller Firms and Larger Firms, respectively. The definitions of all variables can be found in Table A1 in the Appendix. Standard errors (presented in parentheses) are clustered at firm level. ***,**, and * indicate significance at the $1 \%, 5 \%$, and $10 \%$, respectively.

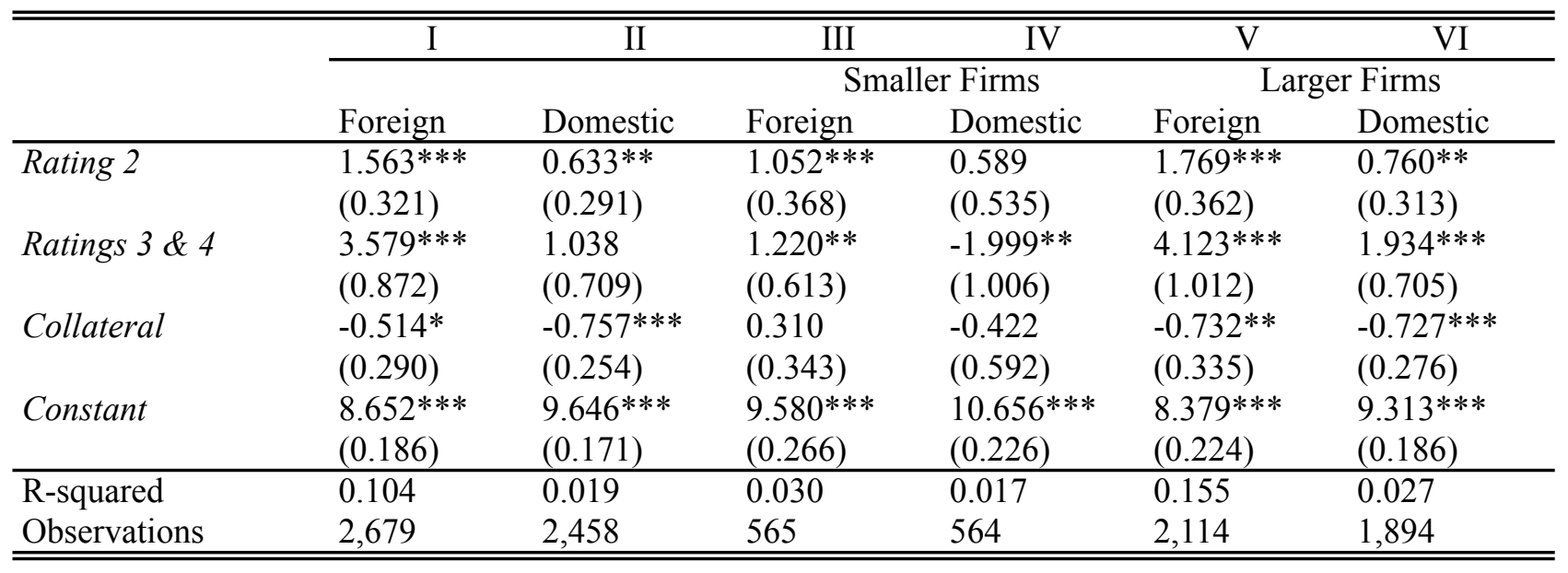




\section{Table 10: What Drives Distance-Related Information Constraints?}

Columns I-III report modified specifications of the Collateral, Maturity, and Loan Spread models. Panel A distinguishes foreign banks into foreign branches and foreign subsidiaries using specifications equivalent to those reported in columns III and VII of Table 3 and column III of Table 4 with Firm $\times$ Time Fixed Effects. The model is estimated with OLS using a sample of 689 loans to 30 firms that received a new loan from at least one domestic bank, one foreign branch and one foreign subsidiary in the same month during the period March 1999 to December 2003 (Restricted Sample). Panel B relaxes the constraint that firms must be borrowing from all three types of banks in the same month and considers a sample of firms borrowing from the three types of banks at any point during the sample period, resulting in a sample of 7,040 loans to 117 firms (Larger Sample). The Firm $\times$ Time Fixed Effects are thus replaced with Firm and Time Fixed Effects. Panels C and D present specifications similar to Panel B allowing for interactions with Time Since Entry/Foreign Owned and Non-Local. The definitions of all variables are in Table A1 in the Appendix. Standard errors, in parentheses, are clustered at firm level. $* * *, * *$, and $*$ indicate significance at the $1 \%, 5 \%$, and $10 \%$, respectively.

\begin{tabular}{|c|c|c|c|}
\hline & $\mathrm{I}$ & II & III \\
\hline & Collateral & Maturity & Loan Spread \\
\hline \multicolumn{4}{|l|}{ A. Branches vs. Subsidiaries - Restricted Sample } \\
\hline Foreign Branch & $\begin{array}{l}0.422 * * * \\
(0.080)\end{array}$ & $\begin{array}{l}0.103 \\
(0.101)\end{array}$ & $\begin{array}{l}-1.633^{* * *} \\
(0.392)\end{array}$ \\
\hline Foreign Subsidiary & $\begin{array}{l}0.150^{*} \\
(0.086)\end{array}$ & $\begin{array}{l}-0.226^{* * *} \\
(0.077)\end{array}$ & $\begin{array}{l}-1.371 * * * \\
(0.297)\end{array}$ \\
\hline R-squared & 0.466 & 0.509 & 0.706 \\
\hline Observations & 689 & 689 & 689 \\
\hline T-test Branches vs. Subsidiaries (p-values) & 0.018 & 0.022 & 0.457 \\
\hline \multicolumn{4}{|l|}{ B. Branches vs. Subsidiaries - Larger Sample } \\
\hline Foreign Branch & $\begin{array}{l}0.438 * * * \\
(0.052)\end{array}$ & $\begin{array}{l}-0.209^{* * *} \\
(0.044)\end{array}$ & $\begin{array}{l}-1.819^{* * *} \\
(0.218)\end{array}$ \\
\hline Foreign Subsidiary & $\begin{array}{l}0.126^{* * * *} \\
(0.040)\end{array}$ & $\begin{array}{l}-0.443^{* * *} \\
(0.059)\end{array}$ & $\begin{array}{l}-0.989^{* * *} \\
(0.181)\end{array}$ \\
\hline $\begin{array}{l}\text { R-squared } \\
\text { Observations }\end{array}$ & $\begin{array}{l}0.326 \\
7,040\end{array}$ & $\begin{array}{l}0.507 \\
7,040\end{array}$ & $\begin{array}{l}0.603 \\
7,040\end{array}$ \\
\hline T-test Branches vs. Subsidiaries (p-values) & 0.000 & 0.000 & 0.000 \\
\hline \multicolumn{4}{|l|}{ C. Time since Entry/Foreign Owned - Larger Sample } \\
\hline Foreign Branch & $\begin{array}{l}0.768^{* * * *} \\
(0.106)\end{array}$ & $\begin{array}{l}-0.568^{* * *} \\
(0.107)\end{array}$ & $\begin{array}{l}-0.580 \\
(0.507)\end{array}$ \\
\hline Foreign Subsidiary & $\begin{array}{l}-0.147 * * * \\
(0.052)\end{array}$ & $\begin{array}{l}0.035 \\
(0.064)\end{array}$ & $\begin{array}{l}-0.277 \\
(0.297)\end{array}$ \\
\hline Foreign Branch $\times$ Time Since Entry & $\begin{array}{l}-0.100^{* * *} \\
(0.032)\end{array}$ & $\begin{array}{l}0.122 * * * \\
(0.031)\end{array}$ & $\begin{array}{l}-0.349^{* *} \\
(0.143)\end{array}$ \\
\hline Foreign Subsidiary $\times$ Time Since Foreign Owned & $\begin{array}{l}0.167 * * * \\
(0.035)\end{array}$ & $\begin{array}{l}-0.286^{* * *} \\
(0.041)\end{array}$ & $\begin{array}{l}-0.440 * * * \\
(0.145)\end{array}$ \\
\hline $\begin{array}{l}\text { R-squared } \\
\text { Observations }\end{array}$ & $\begin{array}{l}0.345 \\
7,040\end{array}$ & $\begin{array}{l}0.525 \\
7,040\end{array}$ & $\begin{array}{l}0.607 \\
7,040\end{array}$ \\
\hline \multicolumn{4}{|l|}{ D. Geographical Distance - Larger Sample } \\
\hline Foreign Branch & $\begin{array}{l}0.444 * * * \\
(0.054)\end{array}$ & $\begin{array}{l}-0.159 * * * \\
(0.046)\end{array}$ & $\begin{array}{l}-1.503^{* * *} \\
(0.263)\end{array}$ \\
\hline Foreign Subsidiary & $\begin{array}{l}0.143^{* *} \\
(0.065)\end{array}$ & $\begin{array}{l}-0.305^{* * *} \\
(0.076)\end{array}$ & $\begin{array}{l}-1.019 * * * \\
(0.244)\end{array}$ \\
\hline Foreign Subsidiary $\times$ Non-Local & $\begin{array}{l}-0.028 \\
(0.081)\end{array}$ & $\begin{array}{l}-0.232 * * \\
(0.089)\end{array}$ & $\begin{array}{l}0.143 \\
(0.337)\end{array}$ \\
\hline Non-Local & $\begin{array}{l}-0.013 \\
(0.052)\end{array}$ & $\begin{array}{l}-0.039 \\
(0.055)\end{array}$ & $\begin{array}{l}-0.590 * * \\
(0.279)\end{array}$ \\
\hline $\begin{array}{l}\text { R-squared } \\
\text { Observations }\end{array}$ & $\begin{array}{l}0.327 \\
7,040\end{array}$ & $\begin{array}{l}0.511 \\
7,040\end{array}$ & $\begin{array}{l}0.606 \\
7,040\end{array}$ \\
\hline Foreign Subsidiary + Foreign Subsidiary $\times$ Non-Local & $\begin{array}{l}0.114 * * \\
(0.049)\end{array}$ & $\begin{array}{l}-0.537 * * * \\
(0.071)\end{array}$ & $\begin{array}{l}-0.876^{* * * *} \\
(0.253)\end{array}$ \\
\hline
\end{tabular}




\section{Table 11: Bank Ownership and Ex Post Loan Performance}

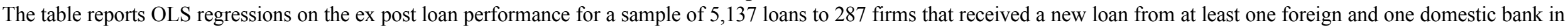
the same month during the period March 1999 to December 2003. In each panel, we report specifications using different measures of ex post loan performance as a dependent variable. In Panel A, we use a dummy variable Arrears or Default that equals one if a loan is in arrears for more than 30 days or is downgraded to the default status (rating 5) and zero otherwise. In Panel B, we use the net return on loans as indicated by equation (3) minus each bank's cost of deposit at loan origination. For each specification, we report the foreign bank coefficient, the constant term, the R-squared, and the number of observations. We estimate each model for all loans, for secured and unsecured loans separately, and for loans with maturities below and above the sample median. For Arrears or Defaults and Net Returns on Loans, we also estimate the model separately for secured and unsecured loans each with shorter and longer maturities including in all cases Firm $\times$ Time Fixed Effects. The definitions of all variables can be found in Table A1 in the Appendix. Standard errors (reported in parentheses) are clustered at firm level. ${ }^{* *}, * *$, and $*$ indicate significance at the $1 \%, 5 \%$, and $10 \%$, respectively.

\begin{tabular}{|c|c|c|c|c|c|c|c|c|c|}
\hline & \multirow{2}{*}{ All Loans } & \multirow{2}{*}{ Secured } & \multirow{2}{*}{ Unsecured } & \multirow{2}{*}{ Shorter Maturity } & \multirow{2}{*}{ Longer Maturity } & \multicolumn{2}{|c|}{ Secured } & \multicolumn{2}{|c|}{ Unsecured } \\
\hline & & & & & & Shorter Maturity & Longer Maturity & Shorter Maturity & Longer Maturity \\
\hline \multicolumn{10}{|l|}{ A. Arrears or Default } \\
\hline \multirow[t]{2}{*}{ Foreign Bank } & $0.035 * *$ & 0.016 & $0.044 *$ & 0.021 & $0.078 * * *$ & 0.030 & 0.016 & 0.034 & $0.077 *$ \\
\hline & $(0.015)$ & $(0.025)$ & $(0.025)$ & $(0.015)$ & $(0.026)$ & $(0.030)$ & $(0.027)$ & $(0.029)$ & $(0.042)$ \\
\hline \multirow[t]{2}{*}{ Constant } & $0.048 * * *$ & $0.068 * * *$ & $0.041 * * *$ & $0.041 * * *$ & $0.044 * * *$ & 0.039 & $0.093 * * *$ & $0.032 * *$ & $0.041 * *$ \\
\hline & $(0.008)$ & $(0.019)$ & $(0.010)$ & $(0.009)$ & $(0.012)$ & $(0.024)$ & $(0.017)$ & $(0.013)$ & $(0.017)$ \\
\hline Firm $\times$ Time Fixed Effects & Yes & Yes & Yes & Yes & Yes & Yes & Yes & Yes & Yes \\
\hline R-squared & 0.554 & 0.781 & 0.632 & 0.665 & 0.707 & 0.799 & 0.887 & 0.736 & 0.772 \\
\hline Observations & 5,137 & 1,698 & 3,439 & 2,705 & 2,432 & 1,005 & 693 & 1,700 & 1,739 \\
\hline \multicolumn{10}{|l|}{ B. Net Return on Loans } \\
\hline \multirow[t]{2}{*}{ Foreign Bank } & $-1.260 * * *$ & -0.687 & $-1.731 * * *$ & $-0.817 * * *$ & $-1.685 * * *$ & 0.117 & $-1.168 *$ & $-1.396 * * *$ & $-2.056 * * *$ \\
\hline & $(0.215)$ & $(0.500)$ & $(0.316)$ & $(0.252)$ & $(0.328)$ & $(0.837)$ & $(0.627)$ & $(0.416)$ & $(0.494)$ \\
\hline \multirow[t]{2}{*}{ Constant } & $11.197 * * *$ & $10.625 * * *$ & $11.470 * * *$ & $10.926 * * *$ & $11.416 * * *$ & $9.782 * * *$ & $11.221 * * *$ & $11.415 * * *$ & $11.512 * * *$ \\
\hline & $(0.112)$ & $(0.364)$ & $(0.132)$ & $(0.143)$ & $(0.153)$ & $(0.666)$ & $(0.394)$ & $(0.181)$ & $(0.198)$ \\
\hline Firm $\times$ Time Fixed Effects & Yes & Yes & Yes & Yes & Yes & Yes & Yes & Yes & Yes \\
\hline R-squared & 0.650 & 0.851 & 0.710 & 0.804 & 0.732 & 0.919 & 0.904 & 0.832 & 0.789 \\
\hline Observations & 5,102 & 1,693 & 3,409 & 2,686 & 2,416 & 1,000 & 693 & 1,686 & 1,723 \\
\hline
\end{tabular}


Table 12: Sample Selection and Competition Effects

The table reports modified OLS regressions during the period March 1999 to December 2003. Panel A uses the "Universe" of 32,279 loans to 2,672 firms, Panel B a sample of 9,382 loans to 1,699 firms that have a single relationship with a foreign or domestic bank for the whole sample period. In Panels C to E, we split the main sample of 5,137 loans into 2,330 cases where the domestic bank was first, in 2,417 cases where the foreign bank was first, and in 390 cases where the foreign and domestic banks granted the loans on exactly the same day. Columns I-III report specifications equivalent to those reported in Columns III and VII of Table 3 and Column III of Table 4. In Panels A to B, we use firm and time fixed effect and firm $\times$ time fixed effects in Panels $\mathrm{C}$ to E. Collateral is a dummy variable indicating whether the loan contract includes the pledge of collateral. Maturity is the natural logarithm of one plus the number of months between loan origination and maturity and Loan Spread is the loan interest rate minus the rate on US Treasury securities of comparable maturity at loan origination. Standard errors (presented in parentheses) are clustered at firm level. ***,**, and * indicate significance at the $1 \%, 5 \%$, and $10 \%$, respectively.

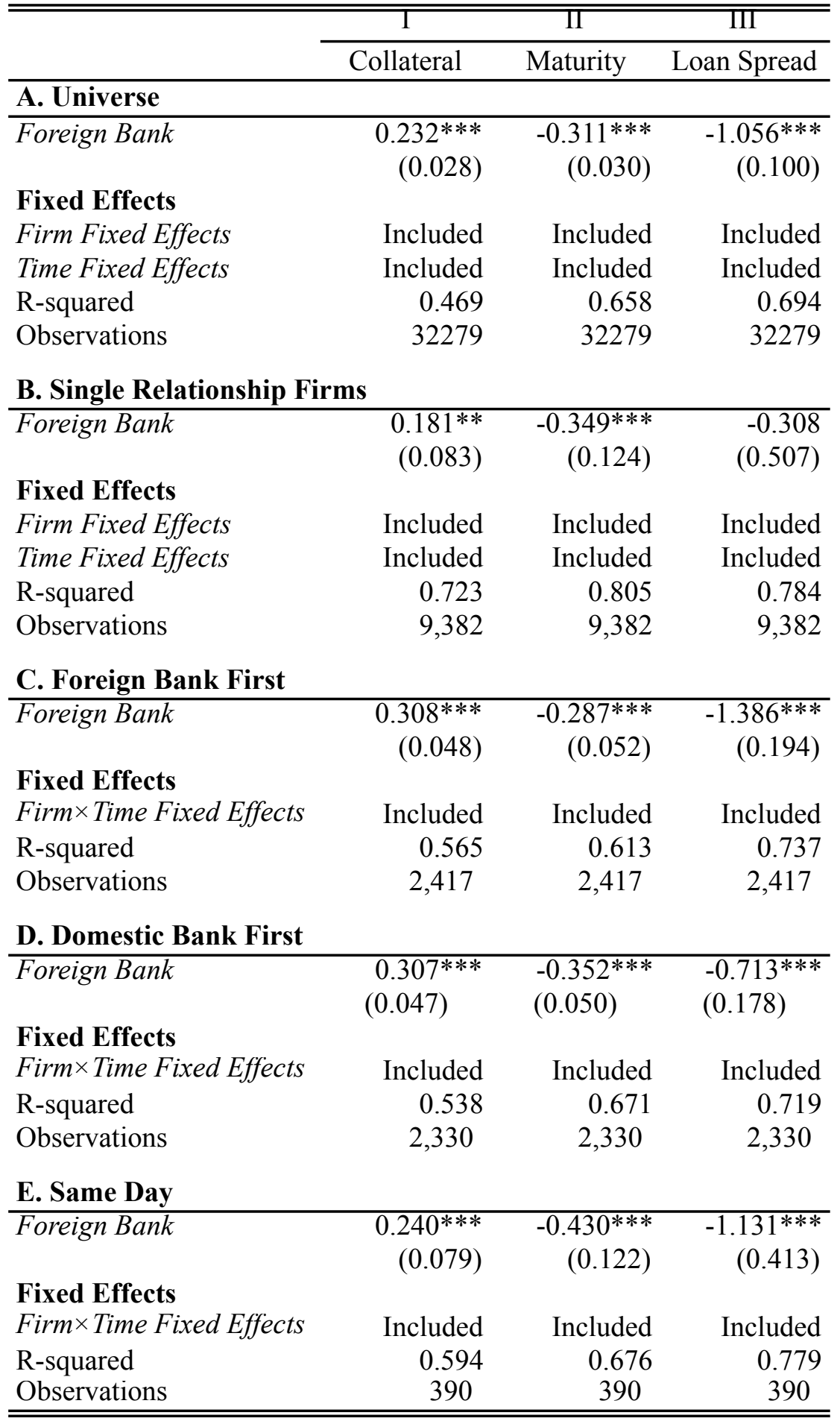


Table 13: Contract Terms, Bank Ownership, and Bank Size

The table reports OLS regressions for a sample of 5,134 loans to 287 firms that received a new loan from at least one foreign and one domestic bank in the same month during the period March 1999 to December 2003. The sample size is smaller than in the benchmark regressions as bank size is not observed for all banks. Global Bank Size equals the natural logarithm of the originating bank's total assets globally. Local Bank Size equals the natural logarithm of the originating bank's total assets in Bolivia. Columns I-III report augmented specifications of the Collateral, Maturity, and Loan Spreads models with all control variables where we add Global Bank Size among the bank characteristics and in columns IV-VI we add Local Bank Size. Collateral is a dummy variable indicating whether the loan contract includes the pledge of collateral. Maturity is the natural logarithm of one plus the number of months between loan origination and maturity and Loan Spread is the loan interest rate minus the rate on US Treasury securities of comparable maturity at loan origination. The definitions of all variables can be found in Table A1 in the Appendix. Standard errors (presented in parentheses) are clustered at firm level. $* * *, * *$, and $*$ indicate significance at the $1 \%$, $5 \%$, and $10 \%$, respectively.

\begin{tabular}{|c|c|c|c|c|c|c|}
\hline & $\mathrm{I}$ & II & III & IV & $\mathrm{V}$ & VI \\
\hline & Collateral & Maturity & Loan Spread & Collateral & Maturity & Loan Spread \\
\hline \multicolumn{7}{|l|}{ Bank Characteristics } \\
\hline Foreign Bank & $\begin{array}{l}0.195 * * * \\
(0.042)\end{array}$ & $\begin{array}{l}-0.376^{* * *} \\
(0.053)\end{array}$ & $\begin{array}{l}-0.743^{* * *} \\
(0.166)\end{array}$ & $\begin{array}{l}0.205^{* * *} \\
(0.035)\end{array}$ & $\begin{array}{l}-0.306^{* * *} \\
(0.042)\end{array}$ & $\begin{array}{l}-1.060 * * * \\
(0.150)\end{array}$ \\
\hline Global Bank Size & $\begin{array}{l}0.032 * * \\
(0.013)\end{array}$ & $\begin{array}{l}0.043 * * * \\
(0.010)\end{array}$ & $\begin{array}{l}-0.129 * * * \\
(0.041)\end{array}$ & & & \\
\hline Local Bank Size & & & & $\begin{array}{l}-0.186^{* * * *} \\
(0.016)\end{array}$ & $\begin{array}{l}-0.104 * * * \\
(0.026)\end{array}$ & $\begin{array}{l}0.019 \\
(0.088)\end{array}$ \\
\hline \multicolumn{7}{|l|}{ Firm Characteristics } \\
\hline Rating 2 & $\begin{array}{l}0.157 * * * \\
(0.057)\end{array}$ & $\begin{array}{l}-0.001 \\
(0.097)\end{array}$ & $\begin{array}{l}0.434^{* *} \\
(0.217)\end{array}$ & $\begin{array}{l}0.103 * * \\
(0.048)\end{array}$ & $\begin{array}{l}-0.043 \\
(0.098)\end{array}$ & $\begin{array}{l}0.513 * * \\
(0.239)\end{array}$ \\
\hline Ratings $3 \& 4$ & $\begin{array}{l}-0.145 \\
(0.096)\end{array}$ & $\begin{array}{l}-0.158 \\
(0.175)\end{array}$ & $\begin{array}{l}0.541 \\
(0.519)\end{array}$ & $\begin{array}{l}-0.128 \\
(0.095)\end{array}$ & $\begin{array}{l}-0.176 \\
(0.175)\end{array}$ & $\begin{array}{l}0.657 \\
(0.542)\end{array}$ \\
\hline \multicolumn{7}{|c|}{ Relationship Characteristics } \\
\hline Rel Duration & $\begin{array}{l}-0.099 * * * \\
(0.026)\end{array}$ & $\begin{array}{l}-0.132 \\
(0.119)\end{array}$ & $\begin{array}{l}0.009 \\
(0.251)\end{array}$ & $\begin{array}{l}-0.064 * * * \\
(0.024)\end{array}$ & $\begin{array}{l}-0.162 \\
(0.117)\end{array}$ & $\begin{array}{l}0.119 \\
(0.243)\end{array}$ \\
\hline Rel Duration-Square & & $\begin{array}{l}0.025 \\
(0.031)\end{array}$ & $\begin{array}{l}-0.011 \\
(0.065)\end{array}$ & & $\begin{array}{l}0.039 \\
(0.031)\end{array}$ & $\begin{array}{l}-0.047 \\
(0.061)\end{array}$ \\
\hline Rel Scope & $\begin{array}{l}-0.034 \\
(0.040)\end{array}$ & $\begin{array}{l}-0.085 \\
(0.054)\end{array}$ & $\begin{array}{l}0.036 \\
(0.158)\end{array}$ & $\begin{array}{l}0.012 \\
(0.034)\end{array}$ & $\begin{array}{l}-0.078 \\
(0.059)\end{array}$ & $\begin{array}{l}0.116 \\
(0.164)\end{array}$ \\
\hline Primary Bank & $\begin{array}{l}-0.125^{* * *} \\
(0.034)\end{array}$ & $\begin{array}{l}0.119 * * * \\
(0.044)\end{array}$ & $\begin{array}{l}-0.316^{* *} \\
(0.131)\end{array}$ & $\begin{array}{l}-0.068^{* *} \\
(0.032)\end{array}$ & $\begin{array}{l}0.151^{* * *} \\
(0.043)\end{array}$ & $\begin{array}{l}-0.330^{* *} \\
(0.144)\end{array}$ \\
\hline \multicolumn{7}{|l|}{ Other Contract Terms } \\
\hline Installment & $\begin{array}{l}-0.015 \\
(0.035)\end{array}$ & $\begin{array}{l}0.891 * * * \\
(0.070)\end{array}$ & $\begin{array}{l}0.360^{* *} \\
(0.156)\end{array}$ & $\begin{array}{l}-0.007 \\
(0.036)\end{array}$ & $\begin{array}{l}0.869 * * * \\
(0.071)\end{array}$ & $\begin{array}{l}0.534 * * * \\
(0.151)\end{array}$ \\
\hline Loan Amount & $\begin{array}{l}0.030^{* *} \\
(0.012)\end{array}$ & $\begin{array}{l}0.067 * * * \\
(0.024)\end{array}$ & $\begin{array}{l}-0.000 \\
(0.100)\end{array}$ & $\begin{array}{l}0.039 * * * \\
(0.012)\end{array}$ & $\begin{array}{l}0.069 * * * \\
(0.025)\end{array}$ & $\begin{array}{l}0.016 \\
(0.098)\end{array}$ \\
\hline Collateral & & & $\begin{array}{l}-0.282^{*} \\
(0.150)\end{array}$ & & & $\begin{array}{l}-0.357 * * \\
(0.172)\end{array}$ \\
\hline Maturity & & & $\begin{array}{l}-1.134 * * * \\
(0.128)\end{array}$ & & & $\begin{array}{l}-1.187^{* * *} \\
(0.134)\end{array}$ \\
\hline Constant & $\begin{array}{l}-0.039 \\
(0.173)\end{array}$ & $\begin{array}{l}0.798^{* *} \\
(0.320)\end{array}$ & $\begin{array}{l}12.776^{* * * *} \\
(0.995)\end{array}$ & $\begin{array}{l}1.106^{* * *} \\
(0.158)\end{array}$ & $\begin{array}{l}1.670^{* * *} \\
(0.346)\end{array}$ & $\begin{array}{l}11.669^{* * * *} \\
(1.083)\end{array}$ \\
\hline \multicolumn{7}{|l|}{ Fixed Effects } \\
\hline Firm $\times$ Time Fixed Effects & Included & Included & Included & Included & Included & Included \\
\hline R-squared & 0.551 & 0.640 & 0.737 & 0.594 & 0.639 & 0.731 \\
\hline Observations & 5,134 & 5,134 & 5,134 & $\underline{5,134}$ & 5,134 & 5,134 \\
\hline
\end{tabular}


Appendix

Table A1: Definitions of Variables

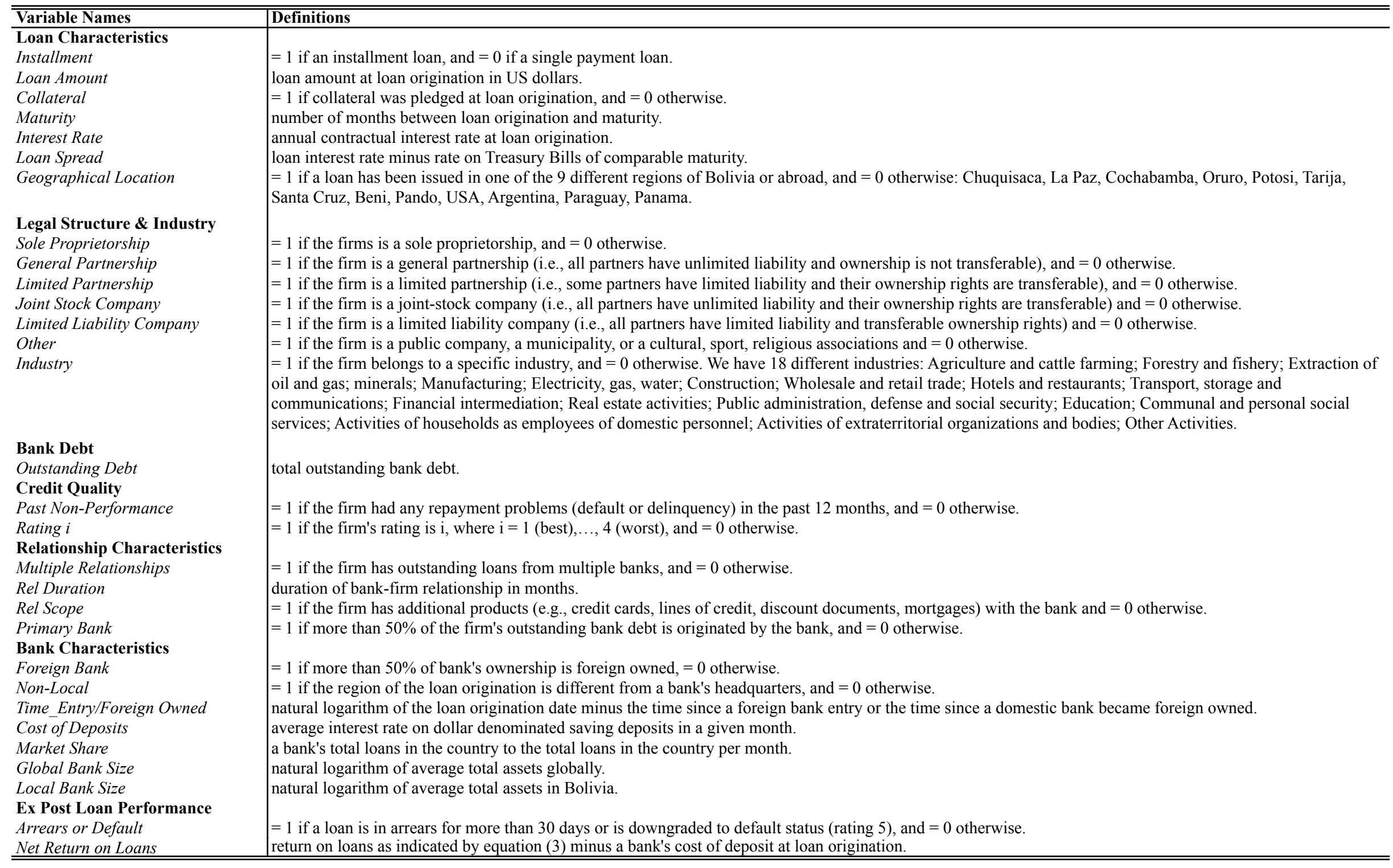

